\begin{tabular}{|l|l|}
\hline $\begin{array}{l}\text { 2. To: (Receiving Organization) } \\
\text { See Distribution Sheet }\end{array}$ & $\begin{array}{l}\text { 3. From: (Originating Organization) } \\
\text { COGEMA Engineering }\end{array}$ \\
\hline $\begin{array}{l}\text { 5. Proj./Prog./Dept./Oiv.: } \\
\text { TWRS: Infrastructure }\end{array}$ & $\begin{array}{l}\text { 6. Design Authority/ Design Agent/Cog. } \\
\text { Engr.: J. R. Freeman-Pollard }\end{array}$ \\
\hline $\begin{array}{l}\text { 8. Originator Renarks: } \\
\text { Ali comments need to be returned to Ms. J. R. Freeman-Pollard by July/6. } \\
1998 .\end{array}$
\end{tabular}

11. Receiver Remarks: 11A. Design Baseline Document? [] Yes [X] No

4. Related EDT No.:
624119

9. Equip. /Component No, ;

N/A
$\begin{array}{r}\text { 10. System/B1og./Facility: } \\ \text { N/A }\end{array}$
12. Major Assm. Owg. No.:
N/A

13. Permit/Permit Application No: N/A

14. Required Response Date: Ju1y 16, 1998

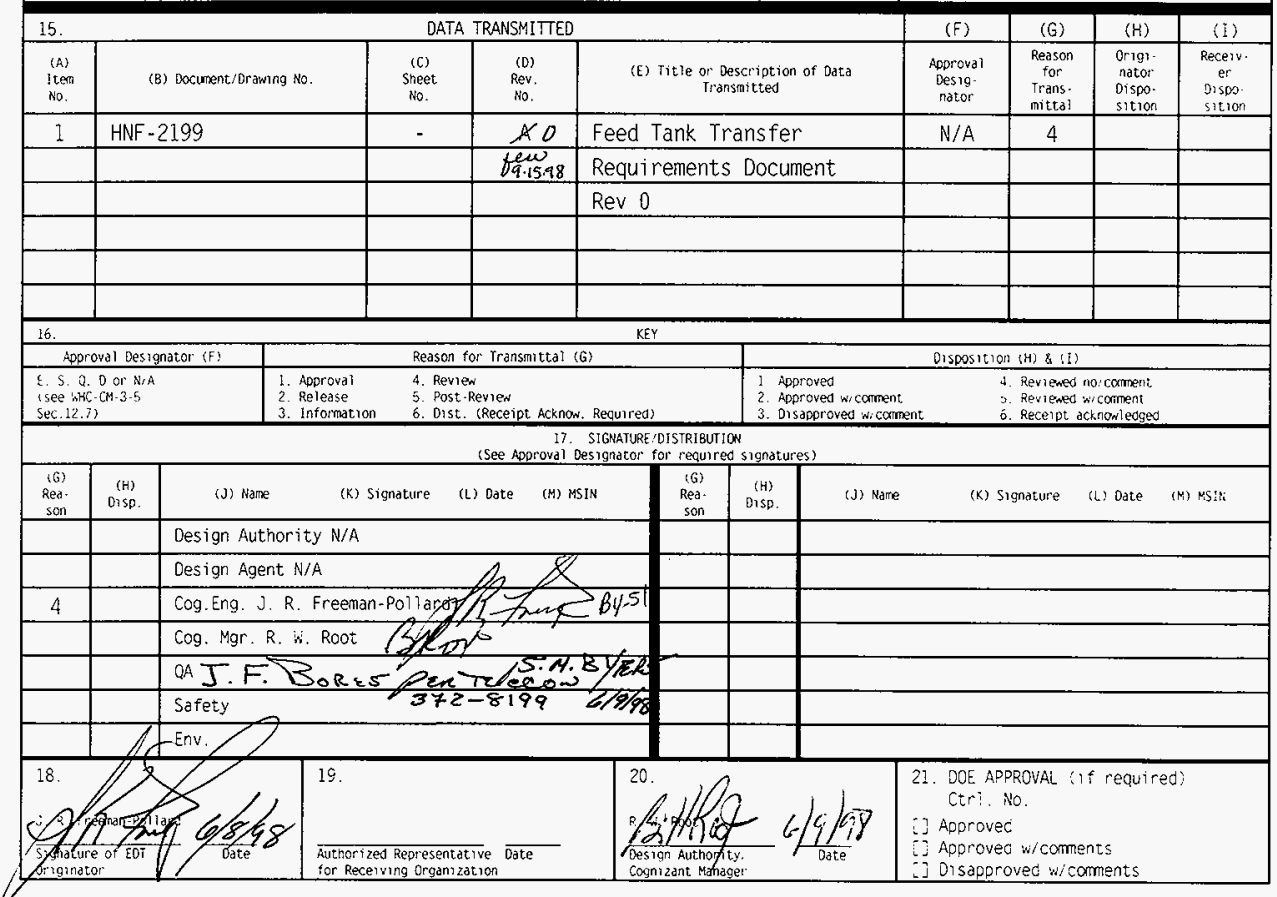

6D-7400-172-2(05/96) GEFO97 
HNF-2199, Rev. 0

\title{
FEED TANK TRANSFER REQUIREMENTS
}

\author{
J. R. Freeman-Pollard
}

COGEMA Engineering Corporation, Richland, WA 99352

U.S. Department of Energy Contract DE-AC06-96RL13200
EDT/ECN: 624121
UC: 2020
Org Code: SS18000
Charge Code: 06303
B\&R Code: EW3130010
Tota1 Pages: 98

Key Words: Feed Tank, Transfer, Requirements, Nuclear Safety, Environmenta1, Engineering, Reporting, AP-106, AP-108, BNFL, LMAES, Privatization Contractor, PC

Abstract: This document presents a definition of tank turnover. Also, DOE and $P C$ responsibilities; TWRS DST permitting requirements; TWRS Authorization Basis (AB) requirements; TWRS AP Tank Farm operational requirements; unreviewed safety question (USQ) requirements are presented for two cases (i.e., tank modifications occurring before tank turnover and tank modification occurring after tank turnover). Finally, records and reporting requirements, and documentation which will require revision in support of transferring a DST in AP Tank Farm to a privatization contractor are presented.

AutoCAD is a registed trademark of AutoDesk, Inc.

TRADEMARK DISCLAIMER. Reference herein to any specific comercial product, process, or service by trade name, trademark, manufacturer, or otherwise, does not necessarily constitute or imply its endorsement, recommendation, or favoring by the United States Goverrment or any agency thereof or its contractors or subcontractors.

Printed in the United States of America. To obtain copies of this document, contact: Document Control Services, P.0. Box 950, Mailstop H6-08, Richland WA 99352, Phone (509) 372-2420;

Fax (509) 376-4989.
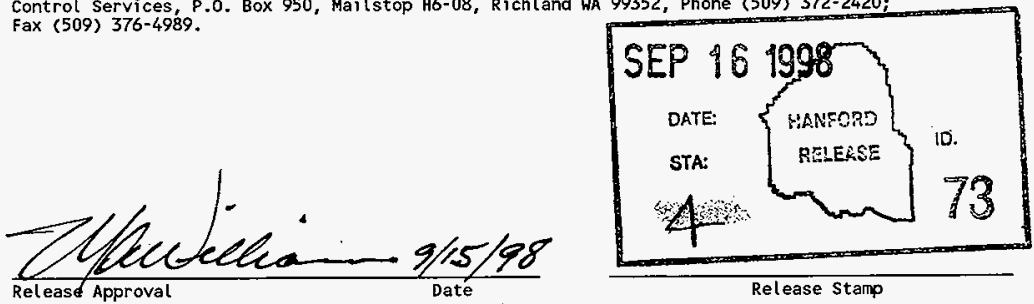

\section{Approved for Public Release}




\section{Feed Tank Transfer Requirements}

Prepared for the U.S. Department of Energy

Fluor Daniel Hanford, Inc.

Hanford Management and Integration Contractor for the

U.S. Department of Energy under Contract DE-ACO6-96RL13200

Approved for Public Release; Further Dissemination Unlimited 


\title{
Feed Tank Transfer Requirements
}

\author{
J. R. Freeman-Pollard \\ COGEMA Engineering Corporation
}

M. L. Deffenbaugh

Lockheed Martin Hanford Corporation

J. P. Harris III

Numatec Hanford Corporation

D. A. Smith

Fluor Daniel Northwest

K. A. White

Lockheed Martin Hanford Corporation

M. W. Cline

J. G. Coenenberg

B. L. Curn

N. M. Menard

Waste Management Federal Services of Hanford

Date Published

June 1998

Prepared for the U.S. Department of Energy

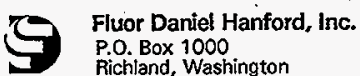

Hantord Management and Integration Contractor for the

U.S. Department of Energy under Contract DE-AC06-96RL13200

Approved for Public Release; Further Dissemination Unlimited 
TRADEMARK DISCLAIMER

Reference herein to any specific commercial product, process, or service by trade name, trademark, manufacturer, or otherwise, does noe necessarily constitute or imply its endorsement, recommendition, or favoring by the United States Government or any agancy thereof or its contractors or subcontractors.

This report has been reproduced from the best avallable copy.

Printed in tho United Ststes of Americe

DISCLM-4.CHP (1-91) 
HNF-2199, Rev. 0

CONTENTS

1.0 INTRODUCTION $\ldots \ldots \ldots \ldots \ldots \ldots \ldots \ldots \ldots \ldots \ldots \ldots \ldots \ldots \ldots, \ldots \ldots \ldots, 1$

$1.1 \quad$ PURPOSE $\ldots \ldots \ldots \ldots \ldots \ldots \ldots \ldots \ldots \ldots \ldots \ldots \ldots \ldots \ldots \ldots \ldots \ldots, 1$

1.2 REPORT ORGANIZATION $\ldots \ldots \ldots \ldots \ldots \ldots \ldots \ldots \ldots \ldots \ldots \ldots, \ldots \ldots \ldots$

2.0 TANK TURNOVER REQUIREMENTS $\ldots \ldots \ldots \ldots \ldots \ldots \ldots \ldots \ldots \ldots \ldots, 2$-I

2.1 DEFINTTION OF FEED TANK TURNOVER $\ldots \ldots \ldots \ldots \ldots \ldots \ldots \ldots, 2-1$

2.2 DOE AND PC INTERFACE RESPONSIBILITIES $\ldots \ldots \ldots \ldots \ldots \ldots \ldots 2-2$

2.2.1 DOE Responsibilities $\ldots \ldots \ldots \ldots \ldots \ldots \ldots, \ldots \ldots \ldots, \ldots, 2-2$

2.2.2 PC Responsibilities $\ldots \ldots \ldots \ldots \ldots \ldots, \ldots \ldots \ldots, \ldots, \ldots, 2-3$

3.0 TWRS DST PERMITTING REQUIREMENTS $\ldots \ldots \ldots \ldots \ldots \ldots \ldots \ldots \ldots \ldots \ldots \ldots \ldots$

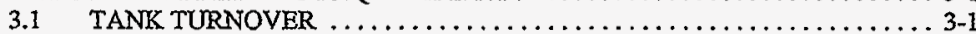

3.2 DST RCRA PERMIT INTERIM VS FINAL STATUS $\ldots \ldots \ldots \ldots \ldots \ldots . .1$

3.2.1 Interim Status Requirements $\ldots \ldots \ldots \ldots \ldots \ldots, \ldots, \ldots \ldots, 3-1$

3.2.2 Final Status Requirements ......................... 3.2

3.3 DST RCRA TANK TURNOVER REQUTREMENTS $\ldots \ldots \ldots \ldots \ldots \ldots, 3-2$

3.3.1 Interim Status Requirements $\ldots \ldots \ldots \ldots \ldots \ldots \ldots \ldots \ldots, \ldots, 3-2$

3.3.2 Finai Status Requirements ........................ 3-3

3.4 AIR OPERATING PERMIT REPORTING REQUIREMENTS $\ldots \ldots \ldots \ldots .3-3$

3.4.1 Semiannual Reports ............................ 3-3

3.4.2 Annual Compliance Certification $\ldots \ldots \ldots \ldots \ldots \ldots \ldots \ldots \ldots, 3-4$

3.4 .3 Transfer of Data $\ldots \ldots \ldots \ldots \ldots \ldots \ldots \ldots \ldots \ldots \ldots \ldots, 3-4$

3.4.4 Data Quality and Format $\ldots \ldots \ldots \ldots \ldots \ldots \ldots \ldots \ldots, 3-5$

4.0 TWRS AUTHORIZATION BASIS REQUTREMENTS $\ldots \ldots \ldots \ldots \ldots \ldots \ldots, 4-1$

4.1 CASE 1: PC MODIFICATION ACTIVITIES OCCUR BEFORE TANK TURNOVER $\ldots \ldots \ldots \ldots \ldots \ldots \ldots \ldots \ldots \ldots \ldots \ldots \ldots \ldots, 4,1$

4.2 CASE 2: PC MODIFICATION ACTIVITIES OCCUR AFTER

TANK TURNOVER $\ldots \ldots \ldots \ldots \ldots \ldots \ldots \ldots \ldots \ldots \ldots \ldots, 4,2$

4.3 EMERGENCY RESPONSE PROCEDURES AND TRAINING $\ldots \ldots \ldots \ldots, 4.3$

4.4 WASTE TREATMENT OPERATIONS $\ldots \ldots \ldots \ldots \ldots \ldots \ldots \ldots, 4,3$

4.5 RETURN OF THE FEED TANKS TO THE DOE $\ldots \ldots \ldots \ldots \ldots \ldots \ldots, 4-3$

5.0 TWRS AP TANK FARM OPERATIONAL AND ENGINEERNG

REQUIREMENTS $\ldots \ldots \ldots \ldots \ldots \ldots \ldots \ldots \ldots \ldots \ldots \ldots \ldots \ldots \ldots \ldots, 5-1$

5.1 CASE 1: TANK TURNOVER OCCURS BEFORE

MODIFICATION ACTIVITIES $\ldots \ldots \ldots \ldots, \ldots \ldots \ldots \ldots \ldots \ldots, \ldots, 1$

5.1 .1 Facility Access Requirements $\ldots \ldots \ldots \ldots \ldots \ldots \ldots \ldots \ldots, 5-1$

5.1 .2 Work Authorization $\ldots \ldots \ldots \ldots \ldots \ldots \ldots \ldots \ldots \ldots \ldots, 5-2$

5.1 .3 Resource Availability ......................... 5-2

5.1 .4 Design Approval $\ldots \ldots \ldots \ldots \ldots \ldots \ldots \ldots \ldots \ldots \ldots \ldots \ldots$. 5-3

5.1 .5 Work Area Congestion $\ldots \ldots \ldots \ldots \ldots \ldots \ldots \ldots \ldots \ldots \ldots, 5-3$

5.1.6 Waste Disposal/Segregation ...................... 5-4

5.2 CASE 2: TANK TURNOVER OCCURS AFTER

MODIFICATION ACTIVITIES $\ldots \ldots \ldots \ldots \ldots \ldots \ldots \ldots \ldots \ldots, 5-4$

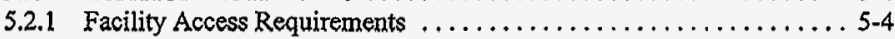


HNF -2199, Rev. 0

\section{CONTENTS (cont'd)}

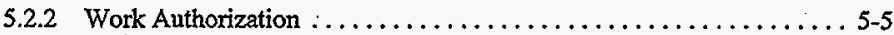

5.2 .3 Resource Availability $\ldots \ldots \ldots \ldots \ldots \ldots \ldots \ldots \ldots \ldots \ldots \ldots, 5-5$

5.2 .4 Design Approval $\ldots \ldots \ldots \ldots \ldots \ldots \ldots \ldots \ldots \ldots \ldots \ldots, 5,6$

5.2 .5 Work Area Congestion $\ldots \ldots \ldots \ldots \ldots \ldots \ldots \ldots \ldots \ldots, 5-6$

5.2.6 Waste Disposal/Segregation $\ldots \ldots \ldots \ldots \ldots \ldots \ldots \ldots \ldots \ldots, 5-7$

6.0 RECORDS AND REPORTNG REQUIREMENTS $\ldots \ldots \ldots \ldots \ldots \ldots \ldots \ldots .6,6-1$

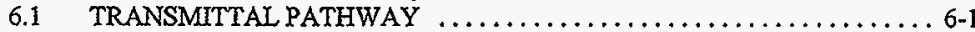

6.1.1 Direct Submission to the Subcontractor Responsible for the Report $\ldots \ldots \ldots \ldots \ldots \ldots \ldots \ldots \ldots \ldots \ldots \ldots \ldots \ldots \ldots, 6-1$

6.1.2 Submission to DOE Who Would Then Provide the Information to the Prime Contractor .......................... $6-1$

6.1.3 Submission to the Prime Contractor Who Would Then Provide the Information to the Appropriate Subcontractor ........... 6-1

6.1.4 Submission of PC Collected Data to the TWRS Subcontractor (i.e., WMH) Who Would Submit the Data along With Its Own Information to Appropriate Parties $\ldots \ldots \ldots, \ldots \ldots \ldots, \ldots, 6,1$

6.2 DATA NEEDS $\ldots \ldots \ldots \ldots \ldots \ldots \ldots \ldots \ldots \ldots \ldots \ldots, 6,2$

7.0 241-AP-106/241-AP-108 DOCUMENTATION REQUIRED FOR

TANK TRANSFER $\ldots \ldots \ldots \ldots \ldots \ldots \ldots \ldots \ldots \ldots \ldots \ldots \ldots \ldots, 7-1$

7.1 241-AP-106 AND 241-AP-108 DESIGN DRAWINGS ............. 7-1

7.2 AP TANK FARM PROCEDURE AND DOCUMENT REVISIONS $\ldots \ldots \ldots 7-1$

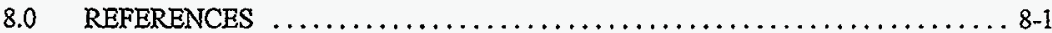


HNF-2199, Rev. 0

\section{ACRONYMS}

$\begin{array}{ll}\text { AB } & \text { authorization basis } \\ \text { AOP } & \text { Air Operating Permit } \\ \text { BIO } & \text { Basis for Interim Operation } \\ \text { DOE } & \text { U.S. Department of Energy } \\ \text { DST } & \text { double-shell tank } \\ \text { ECN } & \text { engineering change notice } \\ \text { Ecology } & \text { Washington State Department of Ecology } \\ \text { FDH } & \text { Fluor Daniel Hanford, Inc. } \\ \text { HGET } & \text { Hanford General Employee Training } \\ \text { ICD } & \text { Interface Control Description } \\ \text { IPT } & \text { Integrated Product Team } \\ \text { ISB } & \text { Interim Safety Basis } \\ \text { LAW } & \text { low-activity waste } \\ \text { LMHC } & \text { Lockheed Martin Hanford Company } \\ \text { M\&I } & \text { management and integration } \\ \text { PC } & \text { privatization contractor } \\ \text { PHMC } & \text { Project Hanford Management Contractor } \\ \text { RCRA } & \text { Resource Conservation and Recovery Act of 1976 } \\ \text { RL } & \text { Richland Operations Office } \\ \text { RU } & \text { regulatory unit } \\ \text { SAA } & \text { Satellite Accumulation Area } \\ \text { TSD } & \text { treatment, storage, and disposal } \\ \text { TWRS } & \text { Tank Waste Remediation System } \\ \text { USQ } & \text { unreviewed safety question } \\ \text { WAC } & \text { Washington Administrative Code } \\ \text { WMH } & \text { Waste Management Federal Services of Hanford, Inc. } \\ & \end{array}$


HNF-2199, Rev. 0

\section{FEED TANK TRANSFER REQULREMENTS}

\subsection{INTRODUCTION}

As part of the contract to acquire Hanford Site tank waste treatment services on a privatization basis, the U.S. Department of Energy (DOE) will transfer double-shell tanks (DST) 241-AP-106 and 241-AP-108 with associated equipment (i.e., pump pits, waste piping, and instrumentation) and land to a privatization contractor(s) (PC). 241-AP-106 and 241-AP-108 will serve as the Low-Activity Waste (LAW) Feed Tanks to the PC's waste treatment facility. LAW feed envelopes will be staged in 241-AP-106/241-AP-108 and then transferred to the PC's waste treatment facility'.

The transfer of 241-AP-106 and 241-AP-108 will permit the PC to accomplish the Phase 1 Privatization Waste Treatment Mission as specified in the Tank Waste Remediation System (TWRS) Privatization contracts TWRS Privatization - BNFL Inc. Contract \#DE-AC06-RL3308 and TWRS Privatization - LMAES Contract \#DE-AC06-RL13309. Phase 1 is divided into Parts $\mathrm{A}$ and $\mathrm{B}$. Part $\mathrm{A}$ is a 20 -month development period to establish the technical, operational, regulatory, business, and financial elements required by the $\mathrm{PC}$ to provide tank waste treatment services on a fixed-unit price basis. Part $B$ is a demonstration that provides tank waste treatment services at a fixed-unit price for a portion of the Hanford Site tank waste.

The PC will provide primary and annulus ventilation systems, instrumentation, equipment, waste piping, instrument, control buildings, and all other items needed to operate 241-AP-106/241-AP-108 independently of the AP Tank Farn while accomplishing the waste treatment mission. PC operational readiness will be determined by the Regulatory Unit (RU) with input from TWRS Waste Disposal Division and Waste Storage Division. The RU will have full authority in determining when the $\mathrm{PC}$ is ready to operate 241-AP-106/241-AP-108 as waste feed tanks. Before completion of the PC's mission, the $\mathrm{PC}$ will be required to restore 241-AP-106 and 241-AP-108 to their original design configuration.

The DOE will operate 241-AP-106/241-AP-108 during the transition period (i.e., the time duration required for the transfer of 241-AP-106/241-AP-108, which may or may not include the actual modifiations to 241-AP-106/241-AP-108), the reconfiguration of AP Tank Farm (i.e., the time duration required for TWRS to reconfigure and operate the remaining six AP Tank Farm DSTs), and the re-establishment of AP Tank Farm (i.e., the time duration required to reconfigure 241-AP-106/241-AP-108 back into AP Tank Farm at the conclusion of Phase 1).

\subsection{PURPOSE}

The purpose of this document is to define tank turnover; present the PC and DOE responsibilities; identify the TWRS DST permitting requirements; identify the TWRS

\footnotetext{
${ }^{1}$ Waste streams generated by the PC during PC operations, are not included in this document.
} 
Authorization Basis $(A B)$ requirements; identify TWRS AP Tank Farm operational requirements; identify unreviewed safety question (USQ) requirements; identify records and reporting requirements, and identify the 241-AP-106/241-AP-108 documentation (i.e., procedures, engineering documents, and drawings) which will require revision in support of waste feed tank modification activities and tank tumover.

In this document the above requirements are presented for two implementation paths. One implementation path addresses turnover of the tanks to the PC before modifications have begun while the other implementation path addresses turnover of the tanks to the PC after modifications and operational readiness testing are completed. Ongoing contract negotiations between DOE and the PC are expected to define the implementation path. Once an implementation path is determined, this document will be modified to reflect the chosen path.

\subsection{REPORT ORGANIZATION}

This document consists of the following sections and appendices in addition to the background:

Section 2.0, Tank Turnover Definition and Interface Responsibilities, provides a definition of tank turnover, PC interface responsibilities and DOE interface responsibilities.

Section 3.0, TWRS DST Resource Conservation and Recovery Act of 1976 (RCRA) Permitting Requirements, provides RCRA interim and final status requirements the PC must meet before assuming operational responsibility.

Section 4.0, TWRS Authorization Basis Requirements, provides the nuclear safety AB requirements the PC (or TWRS acting in behalf of the PC - depending on under whose auspices the modifications are performed) must meet before commencing tank modification activities and before returning the tanks to DOE at the conclusion of the Phase 1 waste treatment mission.

Section 5.0, TWRS AP Tank Farm Operational And Engineering Requirements, provides the TWRS AP Tank Farm operational and engineering facility access; work authorization, resource availability, design approval, work priority, and waste disposal requirements the $\mathrm{PC}$ (or TWRS acting in behalf of the PC - depending on under whose auspices the modifications are performed) must meet before commencing tank modification activities.

Section 6.0, Records and Reporting Requirements, provides the recording and data reporting requirements the $\mathrm{PC}$ must meet and the possible pathways to transmit the data.

Section 7.0, AP Tank Farm Documentation Required for Tank Transfer, provides a summary of the operational procedures, documents and drawings that will need to be revised and/or submitted to the PC upon turnover of 241-AP-106 and 241-AP-108.

Section 8.0, References, lists the references for this report.

Appendices are used to present additional data from Section 7.0 used to prepare this report. To avoid redundancy, such information is incorporated by reference, rather than appended, whenever it is published and readily available to data users. 
HNF-2199, Rev. 0

\subsection{TANK TURNOVER REQUIREMENTS}

\subsection{DEFINITION OF FEED TANK TURNOVER}

Although DOE has committed to turning the operational control of 241-AP-106 and 241-AP-108 over to the PC, the TWRS Privatization contracts do not define what is meant by tank turnover.

The definition of feed tank turnover was not originally believed to be a significant issue because the intent was to make the feed tank totally independent of the balance of the AP Tank Farm. In practice, this will not be happening for three primary reasons. First, Washington State Department of Ecology (Ecology) has made a "determination" that tanks 241-AP-106 and 241-AP-108 should not be removed from the current RCRA permit ${ }^{2}$. Second, the nuclear safety $\mathrm{AB}$ in effect at the time the contract was written (Interim Safety Basis [ISB]) has been superceded by the TWRS $A B$ currently in effect (list of $A B$ documentation given in HNF-IP0842, Volume IV, Section 5.4, Attachment A [Gibson and Hamm 1997]). However, the requirement documents cited in the TWRS Privatization contracts were derived from the ISB and may now be obsolete under the new $\mathrm{AB}$ (of which the Basis for Interim Operation [BIO] constitutes the majority). Third, it was expected that the feed envelopes would be staged well in advance of the PC needs date, and in advance of when the PC needs to begin modifications to 241-AP-106 and 241-AP-108. However, the first batch of conforming waste feed is not scheduled to be transferred to the PC until mid 2001 which is potentially after the PC has assumed operational control of 241-AP-106 and 241-A.P-108 ${ }^{3}$.

Due to the three reasons mentioned above, the definition of feed tank turnover will be determined by the implementation path chosen by $D O E$ and the $P C$. The two implementation paths and associated tank tumover definitions are as follows ${ }^{4}$ :

1) Tank Tumover After Modifications. Definition: Feed Tank Turnover occurs after the PC (or Project Hanford Management Contractor [PHMC] Team or another sub-contractor acting in behalf of the PC) has completed all feed tank modifications, installed associated ancillary equipment (i.e., ventilation system, transfer piping), and can demonstrate operational readiness per a $R U$ approved $A B$. DOE will then turn over operational control of 241-AP-106 and $241-A P-108$ to the PC.

2) Tank Turn Over Before Modifications. Definition: Feed Tank Turnover means that DOE will turn over operational control of 241-AP-106 and 241-AP-108 to the

${ }^{2}$ It is possible that this determination is not a hard and fast requirement and could be reconsidered if compelling reasons exist.

${ }^{3}$ If the PC assumes operational control of 241-AP-106 and 241-AP-108 prior to the transfer of conforming waste feed, the PCs would be operating outside of the TWRS Privatization contract (i.e., storing waste outside of their [DOE] approved envelopes).

\footnotetext{
${ }^{4}$ Award of Phase 18.0 the TWRS Privatization contract will determine the implementation path and associated definition.
} 
HNF-2199, Rev. 0

PC before feed tank modifications and installation of associated ancillary equipment (i.e., ventilation system, transfer piping) occurs.

\subsection{DOE AND PC INTERFACE RESPONSIBILITIES}

The following is a detailed summary of the DOE and PC's interface responsibilities. The responsibilities were obtained from Interface Control Document (ICD) $21 \mathrm{HNP}-\mathrm{SP}-1225$; DOE Memorandum 97-WDD-056, "Clarification of the Requirements and Responsibijities for the Tumover of Double-Shell Tanks (DST) 241-AP-106 and 241-AP-108 to the Privatization Contractor," and Integrated Product Team (IPT) meetings.

\subsubsection{DOE Responsibilities}

The following is a summary of DOE's interface responsibilities:

- Perform waste feed tank inspections prior to turnover to determine the conditions of the tank prior to tumover. The inspection will include, as required, testing and examination of the tanks as well as permitting requirements. The DOE will establish the inspection and permitting requirements with concurrence from Ecology, the PC, and the RU, as applicable.

- Turnover the waste feed tanks to the PC which will include: preparation of a privatization feed tank turnover and requirements document which provides the requirements for the transfer of 241-AP-106 and 241-AP-108 to the PC, preparation of ICD \#21, negotiation (between DOE and the PC) of redundant monitoring, development/modification of safety requirements, operating and maintenance procedures, resolution of any USQs indicating a need for $A B$ (BIO or FSAR, depending on which is in place at the time of turnover) modifications, preparation of a feed tank implementation plan and custody transfer document, and reconfiguration of the AP Tank Farm.

- Provide as-built design information on waste feed tank and ancillary equipment systems to assist the PC in designing, constructing, and implementing the changes required to operate the feed tank independently of the AP Tank Farm. This package will include the certification vendor information, existing tank drawings with applicable Engineering Change Notice (ECN) and specification file, maintenance and operational record for the tank(s), structures, piping, equipment and instrumentation since the tanks were put in service.

- Monitor and maintain the secondary containment tank leak detection system which includes the leak pit and cathodic protection systerns.

- Provide the capacity to receive emergency transfer of tank wastes. The PC is required to provide for the emergency transfer of the feed tank contents back to $D O E$ in the event of a leak in the primary tank. The DOE must provide the spare tank capacity to receive the emergency transfer from the PC, the pipeline 
configuration (excluding the PC's pipeline), and the operational support needed to accomplish the emergency transfer according to approved procedures.

- Allow the PC access to the DOE controlled site, as necessary, to perform repairs, maintenance, and upgrades of their equipment.

- Receive the waste feed tanks from the PC: At the conclusion of Phase 1, the waste feed tank(s) will be returned to DOE. The DOE will perform the design, construction, and installation activities to return the feed tank(s) to the AP Tank Farm and reconfigure the AP Tank Farm to an eight-tank farm, if necessary. These activities include all modification to safety documentation, operating and maintenance procedures, as-built documentation, training of operating and maintenance staff, required acceptance/operational readiness testing, and preparation of a feed tank return implementation plan.

\subsubsection{PC Responsibilities}

The following is a summary of the PC's interface responsibilities:

- Review tank inspection results (as applicable), agree to pre-existing conditions and accept tank.

- Provide and install equipment. This will include monitoring hardware, control systems needed to operate the feed tank(s), and transfer waste.

- The $\mathrm{AB}$ for operation of the feed tanks shall take into consideration the applicable requirements in Strehlow (1997); LMHC (1996), Heubach (1996), and Mulkey (1997).

- Provide all power (excluding what is to be provided by DOE) and consumables required to operate all PC-owned instrumentation and equipment attached to the . waste feed tank.

- Provide and install a ventilation system which includes emissions monitoring systems and disconnection of existing ventilation and monitoring systems in accordance with OSD-T-151-00007.

- Design, construct, and install pipelines from the waste feed tank to and from the PC's waste treatment facility.

- Maintain and operate tank monitoring systems, this excludes the secondary containment tank monitoring system. The DOE leak detection system will monitor the "tertiary" leak detection system for the secondary tank. The PC will monitor the annulus leak detection system which monitors leaks from the primary tank.

- Minimize mixing or blending of different waste envelopes. 
HNF-2199, Rev. 0

- Provide capability for emergency transfer of waste feed tank contents back to DOE.

- Install barriers to separate DOE's controlled property from the PC's controlled property.

- Allow DOE access to the PC-controlled site to perform repair, maintenance, and monitoring of DOE systems.

- Perform final inspection of the feed tank before returning the feed tank to DOE at the conclusion of the mission.

- Issue a final history document which will include as-built drawings of modifications made by the PC. The history document is due upon return of the waste feed $\operatorname{tank}(\mathrm{s})$ to $\mathrm{DOE}$.

- Return the waste feed tank to DOE at the conclusion of the mission with the effective RCRA permit and $A B$. 


\subsection{TWRS DST PERMITTING REQUUREMENTS}

\subsection{TANK TURNOVER}

Since the feed tanks (241-AP-106 and 241-AP-108) are to remain part of the existing . DST System RCRA permits, the interim or final status requirements detailed below will apply to the co-operator (PC) having operational responsibility for these tanks at the time of modification. The RCRA requirements associated with the feed tanks will be the same regardless of the implementation path chosen (i.e., before or after modifications).

At the time the feed tanks are turned over, the PC will be identified as co-operator of its respective tank in the RCRA permitting documents. This will require the PC's certification of permitting documentation associated with their assigned tank prior to tank turnover. This action needs to occur no later than 90 days prior to the transfer of operational control.

\subsection{DST RCRA PERMIT INTERIM VS FINAL STATUS}

The DST System is currently operating under interim status. The DST system is scheduled to be incorporated into the Hanford Facility RCRA Permit (final status) in the second half of calendar year 2000 .

The preferred alternative for accomplishing the tank modifications is to conduct these activities under interim status. Depending on the nature and extent of the modifications to the tanks, a revision to the DST Part A, Form 3, could be required. Regardless of the extent of modifications, it is recommended that Ecology be kept informed of the tank modifications. This will help facilitate future permitting efforts.

Tank modifications that are conducted under final status will require more effort and expense than under interim status. Tank modifications that are conducted under the DST final status permit would require a permit modification that is subject to public review and comment. The permit modification must be finalized prior to starting work. While interim status is preferred, the PC schedule for tank modification and design availability may preclude implementation under interim status. One strategy for remaining under interim status is to revisit the separation of the feed tank from the DST system RCRA permits.

Regardless of whether the tank modifications are conducted under interim or final status, a tank integrity assessment could be required by the RU.

Summarized below are the tank modification RCRA permitting requirements for interim and final status.

\subsubsection{Interim Status Requirements}

- A revised Part A permit application, Form 3, must be submitted to Ecology no later than 90 days prior to transfer of operational control. 
- If waste management capacities are to be increased or different processes are to be implemented, a notice of intent will be required followed by submittal of a revised DST system Part A, Form 3, for Ecology approval prior to implementing the modifications.

- If the existing DST System capacities or processes are not changed, the DST System Part A, Form 3, may need to be revised to reflect the changes in operator and the tank modification design information would be incorporated into the DST system Part $B$ permit application with little or no differentiation between the existing system and modifications for the PC. These activities could be conducted concurrently with the tank modifications and be subject to the same review and public comments as the rest of the DST system. Ecology's review of tank modification information is recommended in order to prevent problems with Ecology's approval of the Part B permit.

- Depending on the nature of the tank modifications, a tank integrity assessment could be required by the RU.

\subsubsection{Final Status Requirements}

- A revised Part B permit application must be submitted to Ecology no later than 90 days prior to transfer of operational control.

- Proposed tank modifications that will impact information required to be included in the Part B Permit will require that a permit modification be requested. This permit modification will need to be finalized prior to implementing the tank modifications.

- Depending on the nature of the tank modifications, a tank integrity assessment could be required by the RU.

\subsection{DST RCRA TANK TURNOVER REQUIREMENTS}

The following summarizes the RCRA interim and final status requirements that must be met prior to DOE turning operational control of the feed tanks over to the PC.

\subsubsection{Interim Status Requirements}

If the transfer of the feed tank occurs while the DST system is under interim status, the following is required:

- A revised Part A must be submitted to Ecology no later than 90 days prior to transfer of operational control. 
HNF-2199, Rev. 0

- The PC must adopt the existing DST interim status documents or develop their own documents to meet the applicable standards of Washington Administrative Code (WAC) 173-303-400.

\subsubsection{Final Status Requirements}

If the tranisfer of the feed tank occurs while the DST system is under final status, the following is required:

- A revised Part B must be submitted to Ecology no later than 90 days prior to transfer of operational control.

- The PC must adopt the final status documents or develop their own documents to meet the applicable standards of WAC 173-303-600.

\subsection{AIR OPERATING PERMIT REPORTING REQUIREMENTS}

Under the provisions of the Hanford Site Air Operating Permit (AOP), the PC will be required to contribute to at least three AOP reports each year. These reports are the two semiannual reports and the annual compliance certification, as described below. Additional PC reporting requirements are located in Section 6.0 .

\subsubsection{Semiannual Reports}

The semiannual reports will be submitted by March $15^{\text {th }}$ and August $15^{\text {th }}$ of each year. The semiaunual report submitted by March $15^{\text {th }}$ will contain information for the period from the previous July 1 through December 31. The semiannual report submitted by August $15^{\text {th }}$ will contain information for the period from the previous January 1 through June 30 . The semiannual reports will be in addition to the currently submitted reports. There are no reporting requirements for insignificant emission units identified by WAC 173-401-530. Each semiannual report will be consistent with WAC 173-401-520.

Each semiannual report will contain the following information for the applicable reporting period (January 1 through June 30 or July 1 through December 31 ).

1. Each semiannual report will provide a reference to reports submitted to the regulatory agencies as required by AOP General Conditions Section 4.5, Permit Deviation Reporting.

2. Each semiannual report will reference source test(s) and/or monitoring reports (required by any regulatory order, e.g., Notice of Construction) that have been issued during the reporting period.

3. Each semiannual report will contain a summary of any air emission compliant investigation(s) required in Attachment 1, Table 2-3 of the Hanford Site AOP and issued during the reporting period. 
4. For all minor radioactive emission points (potential to emit $<0.1 \mathrm{mrem}$ to the maximally exposed individual) listed in Attachment 2, Tables 2.1, 2.2, or Section 2.3 of the Hanford Site AOP, each semiannual report will contain confirmation that any required periodic confirmatory measurements were conducted to verify low emissions during the reporting period.

5. Each semiannual report will list any new regulatory order, (e.g., Notice of Construction) approval conditions imposed during the reporting period by Ecology, the Washington State Department of Health, or the U.S. Environmental Protection Agency, Region 10.

\subsubsection{Annual Compliance Certification}

The annual compliance certification will be submitted by March $15^{\text {th }}$ for the preceding calendar year. The compliance certification will consist of the following:

a. The identification of each term or condition of the Hanford Site AOP that is the basis of the certification.

b. The compliance status.

c. Whether compliance was continuous or intermittent.

d. The method(s) used to determine the compliance status of the source over the reporting period consistent with WAC 173-401-615(3)(a).

No certification is required for insignificant emission units according to WAC 173-401-530(2)(d). The annual report will be certified consistent with WAC 173-401-520.

\subsubsection{Transfer of Data}

The AOP team within the Air and Water Services Group of Waste Management Federal Services of Hanford, Inc. (WMH) is responsible for coordinating and integrating input from the various Flanford Site contractors to compile the semiannual reports and the annual compliance certification. To ensure timely completion of these reports, all Hanford contractors with input to the semiannual reports or the annual compliance certification must adhere to the following schedule for submittal of information and review of the compiled reports:

- A Call Letter with a request for information appropriate to each report will be issued to participating contractors eight weeks before March $15^{\text {th }}$ and August $15^{\text {th }}$ report deadlines.

- Each contractor will have two weeks to assemble information and submit the information to WMH.

- WMH will prepare the first draft of each report and distribute each draft to the contractors for review within one week of receiving all information from the contractors. 
HNF-2199, Rev. 0

- The contractors will have one week to review the initial drafts of the reports and forward any comments they may have to WMH.

- WMH will resolve contractor comments within one week and return the reports to the contractor for certification.

- The contractors will have one week to certify the final draft of the reports and return their certifications to WMH.

- WMH will then have one week to prepare the final report package and deliver this package to the DOE Richland Operations Office (RL).

- $\mathrm{RL}$ will have one week to transmit the reports to the regulators.

\subsubsection{Data Quality and Format}

All data and information transmitted from the PC to WMH for inclusion in AOP semiannual reports or the AOP annual compliance certification must be a quality that allows certification by the PC in accordance with WAC 173-401-520. This regulation addresses certification and includes the following requirements:

"Any application form, report, or compliance certification submitted pursuant to this chapter shall contain certification by a responsible official of truth, accuracy, and completeness. This certification and any other certification required under this chapter shall state that, based on information and belief formed after reasonable inquiry, the statements and information in the document are true, accurate and complete."

Regarding format, information required for completion of AOP reports will be provided both electronically and by paper copy using the Hanford Site standard unless otherwise specified. 


\subsection{TWRS AUTHORIZATION BASIS REQUIREMENTS}

According to the TWRS Privatization Phase 1 contract, the PC will provide ventilation systems, instrumentation, equipment, piping, control systems, and other items required to operate 241-AP-106 and 241-AP-108 (the feed tanks) independent of the rest of the AP Tank Farm.

This section discusses the strategy for developing and maintaining nuclear safety $\mathrm{AB}$ requirements during the modification and testing of the feed tanks, the operation of 241-AP-106 and $241-\mathrm{AP}-108$ as waste feed tariks for the Phase $1 \mathrm{~B}$ privatization waste treatment mission and the return of 241-AP-106 and AP-018 to the DOE at the conclusion of the waste treatment mission.

The assumptions used to develop this section were as follows:

- The PHMC Team will maintain responsibility for the $A B$ for the feed tanks until turnover.

- DOE will be the regulatory approval authority for the feed tanks until turnover.

- The privatization RU will be the regulatory approval authority for the waste feed tanks after turnover.

- Modification and testing of the tanks for utilization by the P.C may occur prior to tank turnover or after tank turnover.

- Identiffication of the physical interfaces between the PHMC Team and the PC will not be addressed in this document. However, the information will be included in an interface control document.

\subsection{CASE 1: PC MODIFICATION ACTIVITIES OCCUR BEFORE TANK TURYOVER}

If modification activities occur before the feed tank is turned over to the PC, the feed tank modification, construction, and testing activities shall be conducted within the requirements of the TWRS $A B$. The following activities will be required to maintain the $A B$ for the feed tanks.

- The design for the tank modifications shall, to the extent practical, incorporate design features that provide the capability for the system to be operated and maintained in accordance with the requirements of the $\mathrm{AB}$. It is recognized that the modifications may involve safety systems for the tank. The PC will be responsible for obtaining any waivers to DOE Orders and Standards and Directives necessary for the modification and testing of the waste feed tanks and related systems.

- The PC will provide design and testing information and technical support for the identification and evaluation of potential hazards for the modification, testing, and operation of the waste feed tanks and the waste treatment facility. The PHMC 
Team will evaluate the changes through the USQ process for a possible modification to the TWRS AB.

- The $A B$ may have to be revised by the PHMC Team prior to the $\mathrm{PC}$ performing feed tank modifications, construction, and testing activities. The process for revision to the TWRS AB is outlined in the Tank Waste Remediation System Retrieval Authorization Basis Amendment Task Plan (Goetz 1998). The revised $\mathrm{AB}$ will provide the basis for the modifications and testing of the waste feed tanks and will address the potential hazards associated with operation of the waste feed tank and the waste treatment facility on the other TWRS facilities. The revised $\mathrm{AB}$ will not provide the safety basis for the operation of the tank as a waste feed tank for the waste treatment facility and will not be subject to review and approval by the RU. (NOTE: The TWRS contractors could prepare and maintain the AB for the operation of the waste feed tank under contract to the PC.) Areas related to the waste feed tanks which may need to be addressed in the amendment include:

- Revised responsibilities for the waste feed tanks.

- Identification and evaluation of any new hazards to TWRS operations related to the modification, testing, maintenance and operation of the waste feed tank and associated systems (the AB for other facilities onsite and the other waste feed tank and waste treatment facility may also be impacted).

- Identification and evaluation of any new hazards to TWRS operations related to construction testing and operation (and decommissioning) of the Phase I waste treatment facility (the $\mathrm{AB}$ for other facilities onsite and the other waste feed tank and waste treatment facility may also be impacted).

- Interface agreements with the PC regarding operation and emergency response.

- The PC will prepare the AB for operation of the waste feed tanks in support of the waste treatment mission (or as noted above, the PC may contract with the TWRS contractors for preparation and maintenance of the $A B$ ).

\subsection{CASE 2: PC MODIFICATION ACTIVITIES OCCUR AFTER TANK TURNOVER}

If modification activities occur after the feed tank is turned over to the PC the following nuclear safety authorization requirements will need to be met:

- The $\mathrm{PC}$ will prepare the $\mathrm{AB}$ for modification, testing, and operation of the waste feed tanks (unless contracted to the PHMC Team to perform).

- The PC will provide design and testing information and technical support for the identification and evaluation of potential hazards for the modification, testing and operation of the waste feed tanks and the waste treatment facility. The PHMC 
Team will evaluate this information through the USQ process for a possible modification to the TWRS $\mathrm{AB}$ as a result of changed hazards resulting from the modification or operation of the PC tanks.

- The TWRS contractor will revise the $A B$ as required to address the potential hazards associated with operation of the waste feed tank and the waste treatment . facility on the other TWRS facilities. This effort will be similar to item 4.1 but will not include the basis for the modification and testing of the waste feed tanks.

\subsection{EMERGENCY RESPONSE PROCEDURES AND TRAINING}

The TWRS contractor will provide training to $P C$ and PHMC Team personnel on TWRS emergency response procedures. The $\mathrm{PC}$ will provide training to site personnel on the $\mathrm{PC}$ emergency response procedures. TWRS personnel involved in the operation of the AP Tank Farms shall be considered facility personnel for the purposes of the accident analysis for the waste feed tanks. Other onsite personnel shall be considered as collocated workers for the purpose of the accident analysis for the waste treatment facilities. PC and contractor personnel involved in the modification, testing, and operation of the waste feed tanks shall be considered facility personnel for the purposes of the TWRS accident analysis. PC and contractor personnel involved in the construction, testing, operation, and decommissioning of the waste treatment facilities shall be considered as collocated workers for the purpose of the TWRS accident analysis. Any AP Farm occurrence reports generated between the PC and the PHMC team will be distributed to all potentially-affected parties.

\subsection{WASTE TREATMENT OPERATIONS}

The $\mathrm{PC}$ will provide the $\mathrm{DOB}$ any information related to any safety issue identified in the operation of the waste feed tank or the waste treatment facility that could impact the operation of other facilities onsite. Similarly, the management and integration (M\&I) contractor will provide the DOE any information related to any safety issue identified in the TWRS facilities or other site facilities which could impact the waste treatment operations. The TWRS contractors and the PC will have responsibility for performing the USQ determinations and any necessary revisions to the $A B$ for their respective facilities (the PC could also contract this to the TWRS contractors for maintenance of the $A B$ for the waste feed tanks).

\subsection{RETURN OF THE FEED TANKS TO THE DOE}

On completion of Phase 1 of the TWRS privatization contract, the following nuclear safety authorization requirements will need to be met prior to return of the waste feed tanks to DOE:

- The PC will provide the TWRS contractor with the current $A B$ and identify any needed changes based on the tank configuration and operation.

- The TWRS contractor will revise the TWRS AB for the return of the tanks. 
HNF-2199, Rev. 0

- The TWRS contractor will prepare a compliance implementation plan if necessary to address any areas where the design and operation of the waste feed tanks are not in accordance with the requirements of the TWRS AB. 


\subsection{TWRS AP TANK FARM OPERATIONAL AND ENGINEERING REQUIREMENTS}

This section provides the TWRS AP Tank Farm operational and engineering facility access, work authorization, resource availability, deșign approval, work priority, and waste disposal requirements that must be met by either the PC, DOE, or PHMC. The TWRS operational and engineering requirements are presented for both implementation paths (i.e., turnover before modifications/construction and tumover after modifications/construction). Also, the TWRS AP Tank Farm operational and engineering requirements are based on the assumption that the feed tanks (241-AP-106 and 241-AP-108) are to remain in the current DST System RCRA Part A and B permits.

\subsection{CASE 1: TANK TURNOVER OCCURS BEFORE MODIFICATION ACTIVITIES}

\subsubsection{Facility Access Requirements}

The following facility access interface requirements (i.e., control, training, and dosimetry) will have to be met by the $\mathrm{PC}$ prior to beginning tank modification/construction activities.

5.1.1.1 Facility Access Control. With the feed tanks (241-AP-106 and 241-AP-108) remaining in the current DST system RCRA Part $A$ and $B$ permits and the minimal physical boundaries identified in the ICDs, PHMC Tank Farm Operations would require a single facility access point to ensure adequate control of their facility boundaries.

This single point facility access equates to the PC not having individual and/or unique access gates and the PC would have to obtain keys from the PHMC Tank Farm Shift Manager to enter their facilities. Pending policy decisions and procedure development on prioritization of PHMC Team and the PC activities, keys would be provided as long as the PC's activity does not result in operational or safety conflicts with other work in the facility. Current policy provides that the prioritization of conflicting activities is at the Shift Manager's discretion.

5.1.1.2 Facility Access Training Requirements. Current training requirements for entry into 241-AP Tank Farm include Hanford General Employee Training (HGET) (including Tank Farm specific training), Tank Farm Facility Orientation, Radiological Worker I, and 24 hour Hazardous Material Worker training. Since access to the PC's facilities will only be possible via entry to the PHMC owned 241-AP Tank Farm, documentation of this training or its equivalent must be provided prior to permission being granted to enter 241-AP. There are currently no procedures or policies in place with guidance on the necessary documentation and proof of equivalency.

5.1.1.3 Dosimetry Requirements. Currently, there are no policies or procedures developed to specify the differences or equivalency of the PC dosimetry requirements to the existing PHMC dosimeter requirements. If the PC dosimetry requirements are determined to be different, the 
HNF-2199, Rev. 0

level of additional dosimetry required for facility access, must be established prior to access being granted.

\subsubsection{Work Authorization}

The following work authorization interface requirements (i.e., document preparation, review/approval and release; lock and tag and excavation and other permits) will have to be met by the PC prior to beginning tank modification/construction activities.

5.1.2.1 Document Preparation. It is assumed that document preparation and format would be the responsibility of the $P C$ and that none of the PHMC procedures and policies affecting document preparation would need to be adhered to.

5.1.2.2 Document Review/Approval. Providing no special permits are required for the work activity, a TWRS AP Tank Farm Operations and Engineering review is not required outside of verification that the work to be performed does not impact any other activities in 241-AP Tank Farm and potentially other interfacing facilities.

5.1.2.3 Document Release. Providing no special permits are required for the work activity, a TWRS AP Tank Farm Operations and Engineering work release is not required outside of verification that the work to be performed does not impact any other activities in 241-AP Tank Farm and potentially other interfacing facilities.

5.1.2.4 Lock and Tag Boundary Issues. DOE and PHMC Team (i.e., TWRS AP Tank Farm Operations and Engineering) must develop, prior to turnover, a policy defining the needs and procedures for overtags and installation of tags affecting equipment outside the facility of origination.

5.1.2.5 Excavation and Other Permits. DOE and PFMC Team (i.e., TWRS AP Tank Farm Operations and Engineering) must develop, prior to turnover, a policy defining the needs and procedures for excavation and other permits (energized work permits, confined space entry, etc.) affecting equipment or locations outside the facility of origination.

\subsubsection{Resource Availability}

The following resource contract interface requirements (i.e., essential staff and support staff limitations) will have to be met by the PC prior to beginning tank modification/construction activities.

5.1.3.1 Limited Staff at PHMC. If policies and procedures developed for facility access require PHMC personnel to escort the PC to their facility, there may be a shortage of trained, available personnel to perform this task.

Since it is unknown how much support the PC will require; the following is the minimum support the PHMC Team believes it will have to provide to the PC: 
HNF-2199, Rev. 0

- Operator - TWRS AP Tank Farm operations support is required if escort services, within AP Tank Farm, are necessary.

- Operations Engineer - TWRS AP Tank Farm operations will provide an Operational Engineer dedicated to the communication and work process flow between TWRS, PHMC Team, and the PC.

- Health Physics Technician - PHMC health physics support is required if escort services, within AP Tank Farm, are necessary.

- Bargaining Unit Contract Re-negotiation Support - The existing bargaining unit contract provides the union halls with a near exclusive right to work activities on the Hanford Site (i.e., AP Tank Farm). If the PC are not held to this contract, terms within the contract may need to be re-negotiated.

\subsubsection{Design Approval}

The following design approval and USQ interface requirements have to be met by the PC prior to beginning tank modification/construction activities.

5.1.4.1 Review and Approval Personnel. It is assumed that the PHMC review, of the PC design, will be limited to the interface points for tie-ins or disconnection. Those aspects of the $\mathrm{PC}$ design affecting these interface points will have to be reviewed and approved by $\mathrm{PHMC}$ Team (i.e., TWRS AP Tank Farm Engineering and Operations). However, any design change which reflects the PC modifications impacting the PHMC facilities will need to be submitted for PHMC review and subsequent approval.

5.1.4.2 USQ Review. Concurrent with the design review and approval of the aspects of the PC design affecting interface points or tie-ins will be the performance and approval of USQ Screenings and Determinations. In some instances, it may become necessary to convene the PHMC Plant Review Committee for decisions concerning specific design attributes. The potential exists that there may need to be modifications and/or additions to the TWRS AB to adequately bound the PC's waste treatment facility configurations.

\subsubsection{Work Area Congestion}

The following work area priority interface requirement has to be addressed by the PHMC Team, DOE, and the PC prior to beginning tank modification/construction activities.

5.1.5.1 Policy for Number of Simultaneous Operations Within AP Tank Farm. The current policy provides Shift Managers with discretionary control over which activities and how many activities can be performed simultaneously in a given facility. This is based on interferences with activities in the specific facility and other interfacing facilities. There is a real potential that there could be as many as six different organizations attempting simultaneous work in the 241-AP facility, after award of the Phase 1B contract. The organizations could include 241-AP-106 PC, 241-AP-108 PC, W-211 project, W-314 project, waste characterization personnel (waste sampling activities), and tank farms operations personnel (surveillances, 
maintenance, transfers, etc.). A guideline for establishing priority for the various conflicting activities must be prepared prior to turnover of 241-AP-106 and 241-AP-108.

In conjunction with the guideline, a procedure or policy identifying the primary organization with the authority to enforce the guideline directions must be prepared. Failure to develop the guideline for establishing work priorities and the procedure/policy enforcing the guideline could result in potential safety hazards to the workers, the environment, and, in the event of an operational upset, the public.

\subsubsection{Waste Disposal/Segregation}

The following waste disposal/segregation interface requirements must be met by the PC prior to beginning tank modification/construction activities.

5.1.6.1 Number of Satellite Accumulation Areas (SAA) in the Farm. Policies and procedures need to be established to determine how waste generated during construction activities will be segregated. This may include directing the $P C$ to establish two new waste streams, one from 241-AP-106 and one from 241-AP-108. The PC would then pay for the disposal of its own waste stream. However, if this concept is not implemented, direction should be provided to identify the method for determining reimbursement of PHMC for disposal of the PC generated waste.

5.1.6.2 Laundry Services. Policies and procedures need to be established to determine how laundry and respirators used by the PC within the 241-AP Tank Farm fence line will be segregated. This may include directing the PC to establish PC specific entry locations for their facilities and have laundry and respirator storage and pick-up from the specific entry locations. The PC would then pay for the treatment of its own laundry and respirators. However, if this concept is not implemented, direction should be provided to identify the method for determining reimbursement of PHMC for treatment of the $\mathrm{PC}$ generated laundry and respirators.

\subsection{CASE 2: TANK TURNOVER OCCURS AFTER MODIFICATION ACTIVITIES}

\section{2:1 Facility Access Requirements}

The following facility access requirements (i.e., control, training and dosimetry) will have to be met by the PC.

PHMC Operations will require a single facility access point to ensure adequate control of their facility boundaries and activities. Single point facility access equates to the PC not having individual unique access gates and that they would have to obtain keys from the PHMC Tank Farm Shift Manager to enter the facility. Pending policy decisions and procedure development on prioritization of PHMC Team and the PC activities, keys would be provided as long as the PC's activity does not resuit in operational or safety conflicts with other work in the facility and the work has been authorized via the work authorization process identified below. Current policy provides that the prioritization of conflicting activities is at the Shift Manager's discretion. 
5.2.1.1 Facility Access Training Requirements. Current training requirements for entry into 241-AP Tank Farm for intrusive work performance include HGET including Tank Farm specific training, Tank Farm Facility Orientation, Radiological Worker II, and 40 hour Hazardous Material Worker training. Documentation of this training or its equivalent must be provided prior to permission being granted to enter 241-AP to perform work. There are currently no procedures or policies in place with guidance on the necessary documentation and proof of equivalency.

5.2.1.2 Dosimetry Requirements. Currently, there are no policies or procedures developed to specify the differences or equivalency of the $\mathrm{PC}$ dosimetry requirements to the existing $\mathrm{PHMC}$ dosimeter requirements. If the $\mathrm{PC}$ dosimetry requirements are determined to not be equivalent, it must be established what level of additional dosimetry is required for facility access.

\subsubsection{Work Authorization}

The following work authorization requirements (i.e., document preparation, review/approval and release; lock and tag and excavation and other permits) will have to be met by the PC.

5.2.2.1 Document Preparation. PC document preparation and format will need to comply with the existing PHMC procedures. Document preparation should be performed by the PC. All of the PHMC procedures and policies affecting document preparation would need to be adhered to.

5.2.2.2 Document Review/Approval. All work documents prepared by the $\mathrm{PC}$ will need to be reviewed and approved by PFMC Team (TWRS AP Tank Farm Operations and Engineering). Design changes reflecting PC/PHMC Team interface details will need to be generated to maintain PHMC configuration control integrity.

5.2.2.3 Document Release. PHMC work release will be required for all activities.

5.2.2.4 Lock and Tag Boundary Issues. The existing lock and tag program will be adhered to for all PC construction work activities.

5.2.2.5 Excavation and Other Permits. The existing PHMC procedures controlling excavation and other permits will be adhered to for all PC construction work activities.

\subsubsection{Resource Availability}

The following resource availability (i.e., essential staff and support staff limitations) and contract requirements will have to be met by the $\mathrm{PC}$.

5.2.3.1 Limited Staff at PHMC. There may be a shortage of trained, available personnel to escort and support the PC construction activities. Since it is unknown how much support the PC will require; the following is the minimum support PHMC Team believes it will have to provide to the PC: 
HNF-2199, Rev. 0

- Operator - TWRS AP Tank Farm operations and engineering support is required for field work support.

- Operations Engineer - TWRS AP Tank Farm will provide an Operational Engineer dedicated to the communication and work process flow between TWRS, PHMC Team, and the PC.

- Health Physics Technician - PHMC health physics support is required for field activities.

- Bargaining Unit Contract Re-negotiation Support - The existing bargaining unit contract provides the union halls with a near exclusive rights to work activities on the Hanford Site (i.e., AP Tank Farm). If the PC are not held to this contract, terms within the contract may need to be re-negotiated.

\subsubsection{Design Approval}

The following design approval and USQ requirements have to be met by the PC.

5.2.4.1 Review and Approval Personnel. PHMC Team review (by TWRS AP Tank Farm Operations and Engineering) of all aspects of the PC design within the 241-AP Tank Farm fence . is required. Those aspects of the $\mathrm{PC}$ design affecting interface points will have to be incorporated into the PHMC configuration control in such a manner that the information will remain with the PEMC after turnover of the tanks.

5.2.4.2 USQ Review. Concurrent with the design review and approval will be the performance and approval of USQ Screenings and Determinations. In some instances, it may become necessary to convene the PHMC Plant Review Committee for decisions concerning specific design attributes. The potential exists that there may need to be modifications and/or additions to the TWRS AB to adequately bound the new facility configurations.

\subsubsection{Work Area Congestion}

The following work area priority requirement has to be addressed by the PHMC Team, $\mathrm{DOE}$, and the PC.

5.2.5.1 Policy for Number of Simultaneous Operations Within AP Tank Farm. The current policy provides Shift Managers with discretionary control over which activities and how many activities can be performed simultaneously in a given facility. This is based on interferences with activities in the specific facility and other interfacing facilities. There is a real potential that there could be as many as six different organizations attempting simultaneous work in the 241-AP facility, after award of the Phase 1B contract. The organizations could include 241-AP-106 PC, 241-AP-108 PC, W-211 project, W-314 project, waste characterization personnel (waste sampling activities), and tank farms operations.personnel (surveillances, maintenance, transfers, etc.). A guideline for establishing priority for the various conflicting activities must be prepared prior to turnover of 241-AP-106 and 241-AP-108. 
HNF-2199, Rev. 0

\subsection{RECORDS AND REPORTING REQUIREMENTS}

On the transfer of 241-AP-106 and 241-AP-108, the PC will assume responsibility for recording and providing data necessary for the development of several reports which are required by various Hanford Site specific regulations and environmental permits.

\subsection{TRANSMITTAL PATHWAY}

Currently, information for the majority of the Hanford Site specific reports is submitted either directly to a Prime Contractor (i.e., Fluor Daniel Hanford [FDH]) or to a subcontractor responsible for compiling the information for the report (i.e., WMH). Depending on the terms of the TWRS Privatization contract, the PC could transmit data a number of ways. The following is a summary of the various pathways the PC could transmit data.

\subsubsection{Direct Submission to the Subcontractor Responsible for the Report}

This is the current method for compiling the necessary data. Also, this is the most direct method and would avoid delays in transmitting the data through various channels to the appropriate subcontractor.

\subsubsection{Submission to DOE Who Would Then Provide the Information to the Prime Contractor}

The Prime Contractor would then supply the data to the subcontractor responsible for compiling the data. Although this option provides the maximum control of the flow of data, it could create significant delays in providing the data to the subcontractor responsible for compiling the report. Also, this option has a high probability for mis-communication of data.

\subsubsection{Submission to the Prime Contractor Who Would Then Provide the Information to the Appropriate Subcontractor}

This option would fulfill the requirement for tracing data submittals. However delays in the transmittal of information from the Prime Contractor to the subcontractor could result in completion delays.

\subsubsection{Submission of PC Collected Data to the TWRS Subcontractor (i.e., WMH) Who Would Submit the Data along With Its Own Information to Appropriate Parties}

This option would best accommodate the PC's inclusion in the TWRS DST System Dangerous Waste Permit which is to be issued by Ecology in November 1999. All TWRS RCRA related reporting and record keeping must be maintained as one treatment, storage, and disposal (TSD) unit. Therefore, the responsibilities and coordination for the submittal of 
FINF-2199, Rev. 0

required reports and upkeep of the DST Unit Operating Record would need to be a joint effort between the PC and the TWRS subcontractor (WMH).

\subsection{DATA NEEDS}

The following table lists the reports and data required by various regulations, permits and DOE Orders that need input from the PC. The table is organized at follows: report title, brief description of the information needed, types of certifications required, if any, and approximate due dates to the PHMC Team, RL, and the regulatory agency, as required. The certification requirement is further described as to whether it is an internal certification, i.e., one that does not require that it accompany the document to the regulator, or as a certification that coes accompany the document to the regulator.

${ }^{5}$ The current understanding is that the $\mathrm{PC}$ will be co-operator with $\mathrm{RL}$ and FDH thus, 7.1.1 or 7.1.4 are the two most likely paths of data transmittal. 
FNF-2199, Rev. 0

\begin{tabular}{|c|c|c|c|c|}
\hline Report & $\begin{array}{l}\text { Information Needed From Private } \\
\text { Contractors }\end{array}$ & $\begin{array}{l}\text { Required by } \\
\text { Contract or } \\
\text { Regulations }\end{array}$ & Certifications & $\begin{array}{l}\text { Approximate } \\
\text { Due Dates }\end{array}$ \\
\hline Annual LDR Report & $\begin{array}{l}\text { Waste inventories and narrative } \\
\text { descriptions of TSD units storing mixed } \\
\text { LDR waste }\end{array}$ & $\begin{array}{l}\text { Tri-Party } \\
\text { Agreement } \\
\text { milestone } \\
\text { M-26-01 }\end{array}$ & None & $\begin{array}{l}\text { To FDH } 4 / 1 \\
\text { To RC } 4 / 15 \\
\text { To EPA Ecology } \\
4 / 30\end{array}$ \\
\hline $\begin{array}{l}\text { Hanford Site } \\
\text { Environmental Report }\end{array}$ & $\begin{array}{l}\text { Compliance with environmental } \\
\text { regulations, current site activities, } \\
\text { accomplishments and issues. Releases of } \\
\text { radionuclides in air/water, hazardous } \\
\text { substances, unplanned environmental } \\
\text { releases, inventories of chemicals effluent } \\
\text { monitoring activities and environmental } \\
\text { surveillance activities }\end{array}$ & $\begin{array}{l}\text { DOE Order } \\
5400.1 \\
\text { (PNNL } \\
\text { coordinates } \\
\text { collection of } \\
\text { information) }\end{array}$ & None & $\begin{array}{l}\text { To RL by } 7 / 31 \text { of } \\
\text { each year }\end{array}$ \\
\hline $\begin{array}{l}\text { EPCRA } \\
\text { Tier II Emergency and } \\
\text { Hazardous Chemical } \\
\text { Inventory }\end{array}$ & $\begin{array}{l}\text { Provide periodic input on inventory of } \\
\text { hazardous materials with annual } \\
\text { verification/certification of information }\end{array}$ & 40 CFR 370 & $\begin{array}{l}\text { Contractors-Internal } \\
\text { Certification } \\
\text { RL - Certification }\end{array}$ & $\begin{array}{l}\text { To PHMC } 1 / 13 \\
\text { To RL } 1 / 31 \\
\text { To Regulator } 3 / 1\end{array}$ \\
\hline $\begin{array}{l}\text { EPCRA } \\
\text { Toxic Chemical Release } \\
\text { Inventory Report }\end{array}$ & $\begin{array}{l}\text { Annual input on use and releases of toxic } \\
\text { chemicals }\end{array}$ & 40 CER 372 & $\begin{array}{l}\text { Contractors- Internal } \\
\text { Certification } \\
\text { RL - Certification }\end{array}$ & $\begin{array}{l}\text { To PHMC } 4 / 14 \\
\text { To RL } 6 / 1 \\
\text { To Regulator } 7 / 1\end{array}$ \\
\hline $\begin{array}{l}\text { Annual Dangerous } \\
\text { Waste Report }\end{array}$ & $\begin{array}{l}\text { Provide information on waste generation } \\
\text { and waste management activities }\end{array}$ & WAC 173.303 & $\begin{array}{l}\text { Contractors-Internal } \\
\text { Certification } \\
\text { RL - Certification }\end{array}$ & $\begin{array}{l}\text { To PHMC } 1 / 13 \\
\text { To RL } 1 / 31 \\
\text { To Regulator } 3 / 1\end{array}$ \\
\hline $\begin{array}{l}\text { PCB Annual Document } \\
\mathrm{Log}\end{array}$ & $\begin{array}{l}\text { Information on TSCA regulated PCB } \\
\text { waste is required for the document log } \\
\text { including waste weights and descriptions, } \\
\text { container ID numbers, manifest } \\
\text { information for PCBs sent off-site for } \\
\text { disposal and date of disposal. }\end{array}$ & $\begin{array}{l}40 \text { CFR } \\
761.180 \\
\text { (TSCA) }\end{array}$ & $\begin{array}{l}\text { None } \\
\text { Not sent to } \\
\text { regulators) }\end{array}$ & $\begin{array}{ll}\text { To FDH } & 4 / 15 \\
\text { To RL } & 6 / 15\end{array}$ \\
\hline
\end{tabular}


HNNF-2199, Rev. 0

\begin{tabular}{|c|c|c|c|c|}
\hline Report & $\begin{array}{l}\text { Information Needed From Private } \\
\text { Contractors }\end{array}$ & $\begin{array}{l}\text { Required by } \\
\text { Contract or } \\
\text { Regulations }\end{array}$ & Certifications & $\begin{array}{l}\text { Approximate } \\
\text { Due Dates }\end{array}$ \\
\hline $\begin{array}{l}\text { PCB Annual Status } \\
\text { Report on Storage of } \\
\text { PCBs }\end{array}$ & $\begin{array}{l}\text { Report requires container ID numbers, } \\
\text { PCB waste weights and descriptions, PCB } \\
\text { out of service dates, and programmatic } \\
\text { information on current or alternative PCB } \\
\text { disposal technologies and data on TSCA } \\
\text { regulated PCB waste that contains } \\
\text { radioactive constituents and PCB waste } \\
\text { that contains both radioactive and RCRA } \\
\text { constituents. }\end{array}$ & $\begin{array}{l}\text { Federal Facility } \\
\text { Compliance } \\
\text { Agreement with } \\
\text { EPA }\end{array}$ & None & $\begin{array}{lc}\text { To RL } & 11 / 4 \\
\text { To HQ } & 12 / 31 \\
\text { To EPA } & 2 / 8\end{array}$ \\
\hline $\begin{array}{l}\text { RCRA Section } 3016 \\
\text { Biennial Report }\end{array}$ & $\begin{array}{l}\text { Data on environmental monitoring, } \\
\text { hydrogeologic site characterization, } \\
\text { environmental contamination, and } \\
\text { response actions is required. Also } \\
\text { information on RCRA TSD Facilities that } \\
\text { managed hazardous waste on or after } \\
\text { November } 19,1980 \text {, including } \\
\text { programmatic data and facility } \\
\text { descriptions. }\end{array}$ & WAC 173-303 & None & $\begin{array}{lr}\text { To RL } & 12 / 15 \\
\text { To HQ } & 1 / 15 \\
\text { To EPA } & 1 / 31\end{array}$ \\
\hline $\begin{array}{l}\text { Effluent Information } \\
\text { System-Onsite } \\
\text { Discharge Information } \\
\text { System }\end{array}$ & $\begin{array}{l}\text { DOE requires its sites to annually compile } \\
\text { and send radionuclide release data, for } \\
\text { both liquid and airborne discharges by } \\
\text { April } 1 \text { of each year. }\end{array}$ & $\begin{array}{l}\text { DOE Order } \\
5400.1\end{array}$ & None & $\begin{array}{l}\text { Submitted to INEL } \\
\text { (INEL has no } \\
\text { funding at this } \\
\text { time to evaiuate } \\
\text { this data. }\end{array}$ \\
\hline Environmental Releases & $\begin{array}{l}\text { This report presents data for radioactive } \\
\text { and non-radioactive substances released } \\
\text { into the environment during each calendar } \\
\text { year. Information includes general } \\
\text { descriptions of facilities, summary of } \\
\text { non-routine releases and spills. }\end{array}$ & $\begin{array}{l}\text { DOE Order } \\
5484.1\end{array}$ & None & $\begin{array}{l}\text { To } R L-10 \text { days } \\
\text { after the end of } \\
\text { quarter. Internal } \\
\text { document only. }\end{array}$ \\
\hline
\end{tabular}


HNF-2199, Rev. 0

\begin{tabular}{|c|c|c|c|c|}
\hline Report & $\begin{array}{l}\text { Information Needed From Private } \\
\text { Contractors }\end{array}$ & $\begin{array}{l}\text { Required by } \\
\text { Contract or } \\
\text { Regulations }\end{array}$ & Certifications & $\begin{array}{l}\text { Approximate } \\
\text { Due Dates }\end{array}$ \\
\hline $\begin{array}{l}\text { Radionuclide Air } \\
\text { Emissions Report }\end{array}$ & $\begin{array}{l}\text { This report includes information on } \\
\text { radionuclides emitted to the atmosphere } \\
\text { from Hanford Site Facilities, an } \\
\text { assessment of the offsite dose to any } \\
\text { member of the public and descriptions of } \\
\text { point sources }\end{array}$ & $\begin{array}{l}\text { WAC 246-247- } \\
080\end{array}$ & $\begin{array}{l}\text { FDH - certification } \\
\mathrm{RL} \text { - certification }\end{array}$ & $\begin{array}{ll}\text { To RL } & 6 / 14 \\
\text { To EPA } & 6 / 30 \\
\text { To DOH } & 6 / 30\end{array}$ \\
\hline $\begin{array}{l}\text { Nonradioactive Air } \\
\text { Emission Inventory } \\
\text { Information }\end{array}$ & $\begin{array}{l}\text { Annually transmit a report on } \\
\text { nonradioactive air emissions to Ecology } \\
\text { containing information on operations } \\
\text { having the potential to emit combustion } \\
\text { products from fossil fuels. }\end{array}$ & WAC $173-400$ & None & $\begin{array}{l}\text { Submitted to } \\
\text { Ecology } 105 \text { days } \\
\text { after January 1st. }\end{array}$ \\
\hline $\begin{array}{l}\text { Hanford Facility RCRA } \\
\text { Permit } \\
\text { General }\end{array}$ & $\begin{array}{l}\text { Requirements for periodic submittals } \\
\text { include: quarterly permit documentation } \\
\text { modifications, Updates to the permit } \\
\text { handbook, annual noncompliance report, } \\
\text { annual permitting status report. } \\
\text { Maintain each TSD unit's operating log } \\
\text { and employee dangerous waste training } \\
\text { records }\end{array}$ & $\begin{array}{l}\text { HF RCRA } \\
\text { Permit } \\
\text { Section II } \\
\qquad \\
\text { HF RCRA } \\
\text { Permit } \\
\text { Section II }\end{array}$ & $\begin{array}{l}\text { subcontractor - } \\
\text { Internal Cert. } \\
\text { Prime - Certification } \\
\text { RL-Certification } \\
\text { None }\end{array}$ & $\begin{array}{l}\text { As required in the } \\
\text { permit } \\
\text { NA }\end{array}$ \\
\hline $\begin{array}{l}\text { Hanford Facility RCRA } \\
\text { Permit Condition II.U \& } \\
\text { V. }\end{array}$ & $\begin{array}{l}\text { Requires TSD units to mark and submit } \\
\text { maps of underground dangerous waste } \\
\text { pipelines that are subject to WAC } \\
\text { regulations. Includes all underground } \\
\text { pipes at a TSD that have carried } \\
\text { dangerous waste at any time since January } \\
1,1980 \text {. If these lines are located outside } \\
\text { of the major fenced areas, these lines must } \\
\text { be marked }\end{array}$ & $\begin{array}{l}\text { HF RCRA } \\
\text { Permit } \\
\text { Condition II.U } \\
\text { and V. }\end{array}$ & None & $\mathrm{NA}$ \\
\hline
\end{tabular}


HNE-2199, Rev. 0

\begin{tabular}{|c|c|c|c|c|}
\hline Report & $\begin{array}{l}\text { Information Needed From Private } \\
\text { Contractors }\end{array}$ & $\begin{array}{l}\text { Required by } \\
\text { Contract or } \\
\text { Regulations }\end{array}$ & Certifications & $\begin{array}{l}\text { Approximate } \\
\text { Due Dates }\end{array}$ \\
\hline $\begin{array}{l}\text { Document } \\
\text { DOE/RL-96-50 }\end{array}$ & $\begin{array}{l}\text { Report for the Mapping and Marking of } \\
\text { Dangerous Waste Underground Pipelines } \\
\text { submitted to Ecology to meet conditions } \\
\text { II.U \& V described above. Private } \\
\text { contractors will need to comply with the } \\
\text { detailed methods identified }\end{array}$ & $\begin{array}{l}\text { HF RCRA } \\
\text { Permit } \\
\text { Condition II U } \\
\text { and V. }\end{array}$ & None & $\begin{array}{l}\text { Document } \\
\text { submitted in } 1996 . \\
\text { Will be updated on } \\
\text { an as needed basis }\end{array}$ \\
\hline $\begin{array}{l}\text { Hanford Facility RCRA } \\
\text { Part A Permit } \\
\text { Applications }\end{array}$ & $\begin{array}{l}\text { Submittal of Part A permit application } \\
\text { documentation for inclusion into the HF } \\
\text { RCRA Permit for interim status. All Part } \\
\text { A Permit application documentation will } \\
\text { be required for incorporation into } \\
\text { DOE/RL-88-21 }\end{array}$ & WAC $173-303$ & $\begin{array}{l}\text { Subcontractor - } \\
\text { Internal Certification } \\
\text { Prime - Certification } \\
\text { RL - Certification }\end{array}$ & $\begin{array}{l}\text { Negotiated with } \\
\text { Ecology and RL. }\end{array}$ \\
\hline $\begin{array}{l}\text { Hanford Facility RCRA } \\
\text { Part B Permit } \\
\text { Applications }\end{array}$ & $\begin{array}{l}\text { Submittal of Part B permit application } \\
\text { documentation for inclusion into the HEF } \\
\text { RCRA Permit for final status }\end{array}$ & WAC $173-303$ & $\begin{array}{l}\text { Subcontractor - } \\
\text { Internal Certification } \\
\text { Prime - Certification } \\
\text { RL - Certification }\end{array}$ & $\begin{array}{l}\text { Negotiated with } \\
\text { Ecology and RI. }\end{array}$ \\
\hline $\begin{array}{l}\text { Hanford Facility Air } \\
\text { Operating Permit }\end{array}$ & $\begin{array}{l}\text { Sitewide air operating permit for Facilities } \\
\text { on the Hanford Site. Data needs include: } \\
\text { permit modification and renewal } \\
\text { information and copies of air permits } \\
\text { (NOCs, PSD). Reports submitted } \\
\text { semiannually and compliance report } \\
\text { submitted annually. }\end{array}$ & WAC 173-401 & $\begin{array}{l}\text { Contractors - internal } \\
\text { certification } \\
\text { RL- Certification }\end{array}$ & $\begin{array}{l}\text { To DOH/EPA } \\
7 / 11\end{array}$ \\
\hline
\end{tabular}


HNF-2199, Rev. 0

\begin{tabular}{|c|c|c|c|c|}
\hline Report & $\begin{array}{l}\text { Information Needed From Private } \\
\text { Contractors }\end{array}$ & $\begin{array}{l}\text { Required by } \\
\text { Contract or } \\
\text { Regulations }\end{array}$ & Certifications & $\begin{array}{l}\text { Approximate } \\
\text { Due Dates }\end{array}$ \\
\hline $\begin{array}{l}\text { Projections of } \\
\text { Anticipated Costs for } \\
\text { Closure and Postclosure }\end{array}$ & $\begin{array}{l}\text { Annual information required for any TSD } \\
\text { unit in final status, undergoing closure, } \\
\text { has been closed or is in postclosure care } \\
\text { during the preceding fiscal year. Detailed } \\
\text { cost estimates for closure or postclosure } \\
\text { care, including any monitoring or } \\
\text { maintenance being performed or } \\
\text { anticipated. }\end{array}$ & $\begin{array}{l}\text { Permit } \\
\text { Section II.H }\end{array}$ & $\begin{array}{l}\text { Subcontractors- } \\
\text { Internal Certification. } \\
\text { Prime contractors - } \\
\text { Certification } \\
\text { RL - Certification }\end{array}$ & $\begin{array}{l}\text { TWRS will not } \\
\text { have a TSD units } \\
\text { incorporated in the } \\
\text { HF RCRA Permit } \\
\text { until } 1999 \text { in } \\
\text { accordance with } \\
\text { Permit } \\
\text { Modification } \\
\text { Schedule, Rev. } 3.0\end{array}$ \\
\hline
\end{tabular}




\subsection{1-AP-106/241-AP-108 DOCUMENTATION REQUIRED FOR TANK TRANSFER}

The operational procedures and documents will be managed in accordance with the PHMC Team's Configuration Management Plan (Vann et al. 1998). All information, in any . form, provided to the PC by the PHMC Team or other government contractors, including and not limited to drawings, specifications, electronic files, letter reports, calculations, analysis reports, etc., the $\mathrm{PC}$ will be responsible for maintaining configuration control over changes to such information as appropriate, using the PC's established configuration management policies and procedures. Implementation of a configuration management system will enable the PC to provide the PHMC Team with timely and accurate documentation (i.e., permits, design drawings, etc.) upon return to the 241-AP-106 and 241-AP-108 at the conclusion of the mission.

\subsection{1-AP-106 AND 241-AP-108 DESIGN DRAWINGS}

A condition of the TWRS privatization contract is the transmittal of design drawings (i.e., as-builts) when 241-AP-106 and 241-AP-108 are turned over to the PC. A total of 353 design drawings have been identified by PHMC Team as needing to be transmitted to the PC. Of these, 274 drawings need to be converted from manual to AutoCAD. Also all the drawings will require outstanding ECN incorporation ${ }^{6}$. See Appendix A for a list of the design drawings to be transmitted to the PC. The list is comprised of the drawings number, the sheet number, the title and an indication (i.e., Y) if the drawing has already been converted to AutoCAD.

\subsection{AP TANK FARM PROCEDURE AND DOCUMENT REVISIONS}

Another condition of the TWRS privatization contract is the identification and revision of TWRS AP Tank Farm operational procedures and documents that will be affected when PC activities (i.e., tank modification, pipeline construction, etc.) commence. A total of 888 operational procedures and documents have been identified by PHMC Team as requiring revision in support of turning over 241-AP-106 and 241-AP-108 to the PC ${ }^{7.8}$. The following is a break down by category of the operational procedures and documents needing revision and the appendices they are located in:

- 45 Plant Operating Procedures (Appendix C)

- 2 Operator Routine Surveillance Procedures (Appendix C)

- 9 Alarm Response Procedures (Appendix C)

- 8 Preventative Maintenance Procedures (Appendix C)

${ }^{6}$ Detailed facility configuration drawings which support interface, connection and PC modifications are not included. These drawings will be identified upon award of the Phase IB contract and captured in ICD 21, HNF-SP-1225.

${ }^{7}$ A checklist developed as an aid in determining if a given administrative procedure would be impacted by the turnover of 241-AP-106 and 241-AP-108 can be found in Appendix B.

${ }^{8}$ The lists of operational procedures and documents needing revision are subject to change due to PHMC procedure and manual changes since the lists were developed. 


\section{HNF-2199, Rev, 0}

- 9 Functional Test Procedures (Appendix $\mathrm{C}$ )

- . 2 Operating Specification Documents (Appendix C)

- 1 Criticality Specification Procedure (Appendix C)

- 455 Administrative Procedures (Appendix D)

- 161 Preventative Maintenance System Component History Files (Appendix E)

- 162 Calibration Data Sheets (Appendix F)

- $\quad 34$ Essential Facility Electrical and Piping and Instrumentation Drawings (Appendix G). 
HNNF-2199, Rev. 0

\subsection{REFERENCES}

Gibson and Hamm, 1997, TWRS Administration, ENNF-IP-0842, Rev. 0, Lockheed Martin Hanford Company, Richland, Washington.

Goetz, T. G., 1998, Tank Waste Remediation System Retrieval Authorization Basis Amendment Task Plan, HNF-1722, Rev. 0, Lockheed Martin Hanford Company, Richland, Washington.

Heubach, E. C., 1996, Double Shell Tank Interim Operational Safety Requirements, WHC-SDWM-OSR-016, Rev. OE, Duke Engineering and Services Hanford Company, Richland, Washington.

LMHC, 1996, Operating Specifications for Tank Farm Leak Detection and Single Shell Tank Intrusion Detection, OSD-T-151-00031, Lockheed Martin Hanford Company, Richland, Washington.

Mulkey, C. H., 1997, Double-Shell Tank Waste Analysis Plan, WHC-SD-WM-EV-053, Rev. 4a, Lockheed Martin Hanford Company, Richland, Washington.

Noorani, Y.G., 1997, Tank Waste Remediation System Basis for Interim Operation, ENNF-SDWM-BIO-001, Rev. OF, DS\&H Hanford, Inc., for Fluor Daniel Hanford, Inc., Richland, Washington.

Strehlow, J. P., 1997, Unclassified Operating Specifications for the 241-AN, AP, AW, $A Y, A Z$, and SY Tank Farms, OSD-T-151-00007, Lockheed Martin Hanford Company, Richland, Washington.

Vann, J. M., E. R. Hamm, and R. D. Crips, 1998, Tank Waste Remedation System Configuration Management Plan, HNF-1900, Rev. 0, Fluor Daniel Hanford, Inc.. January 1998. 
HNF-2199, Rev. 0

APPENDIX A

\section{LISTING OF PRINTS NEEDED FOR TURNOVER}


HNF-2199, Rev. 0

LISTING OF PRINTS NEEDED FOR TURNOVER

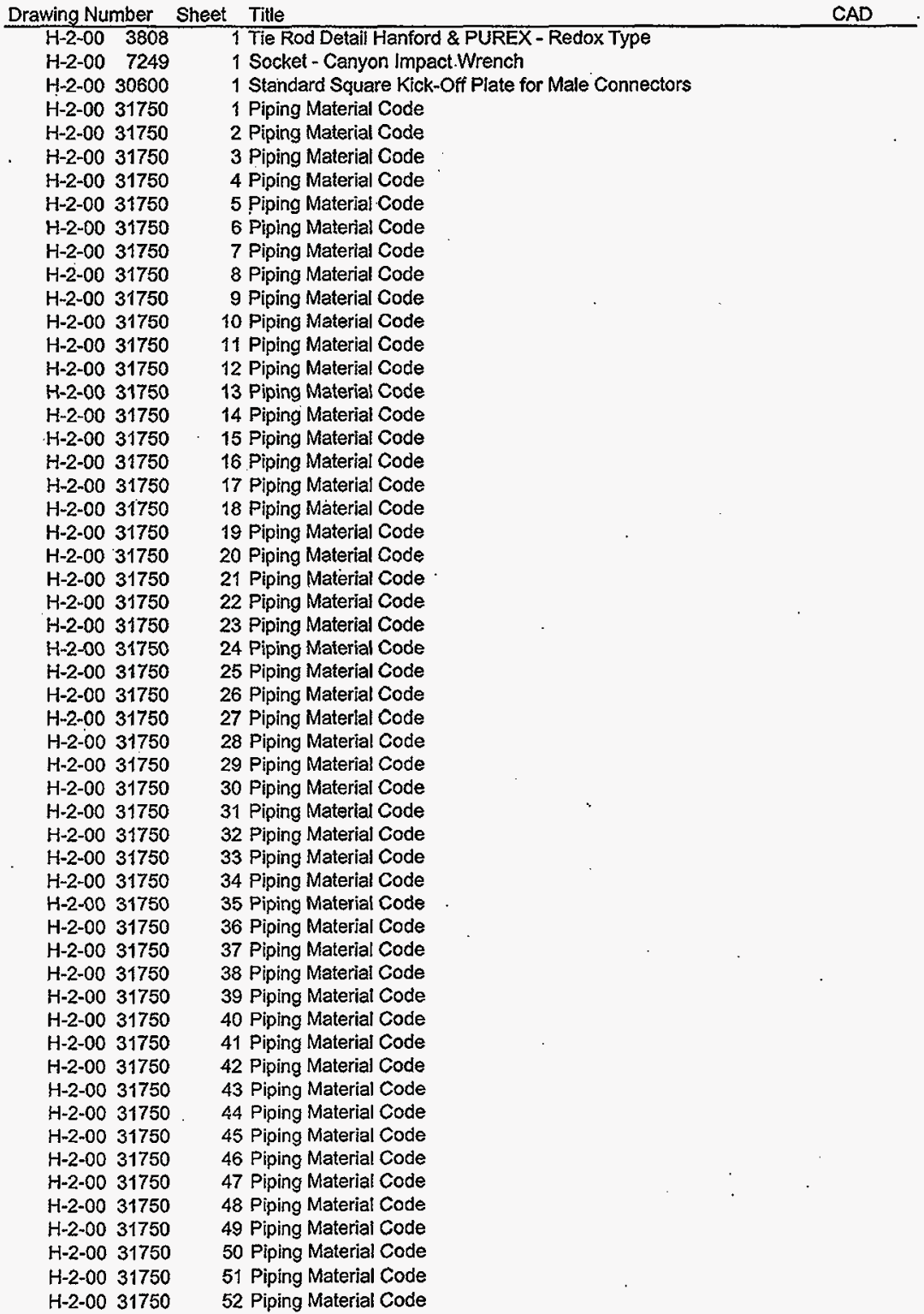


HNNF-2199, Rev. 0

LISTING OF PRINTS NEEDED FOR TURNOVER

Drawing Number Sheet Title

H-2-00 31750

H-2-00 31750

$\mathrm{H}-2-0031750$

H-2-00 31750

$\mathrm{H}-2-00 \quad 31750$

H-2-00 31750

$H-2-0031750$

$H-2-0031750$

H-2-00 31750

H-2-00 31750

H-2-00 31750

H-2-0O 32420

H-2-00 32420

H-2-0O 32420

H-2-00 32421

H-2-00 32423

H-2-00 32423

H-2-00 32423

H-2-00 32430

H-2-00 32430

H-2-00 32431

H-2-00 32433

H-2-00 32433

H-2-00 32433

H-2-00 32446

H-2.00 36382

H-2-00 38088

H-2-00 38654

H-2-00 57331

H-2-0O 57332

H-2-00 57901

H-2-00 63804

H-2-00 68205

H-2-00 68206

H-2-0O 68209

H-2-00 68215

$\mathrm{H}-2-00 \quad 68215$

H-2-00 68218

H-2-00 68218

H-2-00 68219

$\mathrm{H}-2-00 \quad 69897$

$\mathrm{H}-2-0069897$

H-2-00 69897

$\mathrm{H}-2-0069897$

$\mathrm{H}-2-0070001$

$\mathrm{H}-2-00 \quad 73453$

$\mathrm{H}-2-0073453$

H-2-00 90160

H-2-00 90161

H-2-00 90162

H-2-00 90174

H-2-00 90174

H-2-00 90184

H-2-00 90185
53 Piping Material Code

54 Piping Material Code

55 Piping Material Code

56 Piping Material Code

57 Piping Material Code

58 Piping Material Code

59 Piping Material Code

60 Piping Material Code

61 Piping Material Code

62 Piping Material Code

63 Piping Material Code

1 Assembly - Horizontal \& Vertical 2" Connector

2 Assembly - Horizontal \& Vertical $2^{\prime \prime}$ Connector

3 Assembly.- Horizontal \& Vertical 2" Connector

1. Details - 2" Connector Installation

1 Details Connector Block - $2^{n}$ Connector

2 Details Connector Block 3 Way. - 2" Connector

3 Details Connector Block 3 Way - 2" Connector

1 Assembly Horiz \& Vert Conn - 3" Connector

2 Assembly Horiz \& Vert Conn - $3^{\prime \prime}$ Connector

1 Details $3^{\prime \prime}$ Connector Installation

1 Defails Connector Block - $3^{n}$ Connector

2 Details Connector Block 3 Way - 3 " Connector

3 Details Connector Block - 3 " Connector

$\{$ Details - Alloy Steel Male Connector Nozzle 1", 2", 3", 4"

Instrumentation Waste Tank Liquid Level Gauge Installation and

1 Riser Schedule

1 F. I. C. Sleeved Guage Liquid Surveillance

1 Suction Float for Transfer Pump

1 Mechanical Equipement Details Short and Long Dowels

1 Mechanical Eqpt Detail - Studs

1 Flexible Metal Hose Mod and Assy for Process Use

1 Jumper Miscellaneous Details

1 Hook Guide 2" Connector PUREX /REDOX Type

1 Hook Guide $3^{\text {n Connector PUREX Type }}$

1 Operating Nut 2" PUREX/REDOX Type

1 Skirt - Verticle $2^{\text {* }}$ Connector PUREX/REDOX Type

2 Skirt - Verticle 2" Connector PUREXJREDOX Type

1 Skirt - Horizonial $3^{*}$ Connector PUREX/REDOX Type

2 Skirt - Horizontal 3 " Connector PUREXJREDOX Type

1 Skirt - Verticle $3^{\prime \prime}$ Connector PUREXJREDOX Type

1 Modified Pump Discharge Head

2 Sub-Assembly Pump Discharge Head

3 Pump Discharge Head Miscellaneous Details

4 Pump Discharge Head Miscellaneous Details

1 Lifting Bail Tank Farm Pump

1 Std Isolation Blank Assy for PUREX/Hanford Nozzle

2 Std Isolation Blank Assy for PUREX/Hanford Nozzle

1 Standard Folding Bails

1 Standard Rigid Litting Bails

1 Standard Horiz Conn Bails

1 Hook 2" Connector PUREXJREDOX Type

2 Hook 2" Connector PUREXJREDOX Type

1 Male Nozzle f" PUREX

1 Male Nozzle 2" PUREX 
HNF-2199, Rev. 0

LISTING OF PRINTS NEEDED FOR TURNOVER

Drawing Number Sheet Title

$\mathrm{H}-2-0090185$

H-2-00 90186

$\mathrm{H}-2-0090186$

H-2-00 90439

H-2-00 90440

H-2-00 90441

$\mathrm{H}-2-0090442$

$\mathrm{H}-2-0090443$

$\mathrm{H}-2-00 \mathrm{90444}$

H-2-00 90444

$\mathrm{H}-2-0080444$

$\mathrm{H}-2-0090446$

$\mathrm{H}-2-00 \quad 90447$

$\mathrm{H}-2-00 \quad 90447$

$\mathrm{H}-2-0090450$

$\mathrm{H}-2-00 \mathrm{S0453}$

H-2-00 90454

2 Male Nozzle $2^{\prime \prime}$ PUREX

1 Male Nozzle 3" PUREX

2 Male Nozzle 3" ". PUREX

1 Structural Concrete Tank Foundation Plan \& Details

1 Structural Insulating Coricrete Plan \& Details

1 Structural Dome Reinforcement Plan \& Detail

1 Structural Tank Section and Haunch Reinforcement

1 Structural Haunch Reinforcement at Annulus ACS

1 Structural Leak Detection Drain Plans and Sections

2 Piping Leak Detection Drain Plan and Sections

3 Piping Leak Detection Drain Plan and Sections

1 Structural Annulus Pump Pits Plans and Sect

1 Structural Central Pump Pits Plans and Sect

2 Structural Central Pump Pits Plans, Sect and Det

1 Structural Vent Pits Plans and Sections

1 Arch/Strl Details Support Facillies

$\mathrm{H}-2-0090454$

1 Structural Typical Details

2 Structural Typical Details

$\mathrm{H}-2-00 \quad 80454$

H-2-00 90457

H-2-00 90464

H-2-00 90464

$\mathrm{H}-2-0090465$

H-2-00 80465

$\mathrm{H}-2-0090465$

$\mathrm{H}-2-0090466$

H-2-00 90466

H-2-00 90467

H-2-00 90467

H-2-00 90470

H-2-00 90470

$\mathrm{H}-2-0090470$

$H-2-0090470$

$\mathrm{H}-2-0090470$

H-2-00 90470

3 Structural Typical Details

3 Structural Central Exhaust Sta Sections and Det

1 lstn Cone Fon Plan and Det TK-241-AP-101 Thru 108

2 istn Conc Fdn Plan and Det TK-241-AP-101 Thru 108

1 Elec Instm Insulating Concrete Plan and Details

2 Elec Instm Insulating Concrete Plan and Details

3 Elec Instm Insulating Concrete Plan and Details

1 Instrumentation Concrete Shell Plan and Details

2 Instrumentation Concrete Shell Plan and Details

$\{$ Instm Tank Conduit Routing Plan \& Details

2 Instm Tank Conduit Routing Plan \& Details

1 Electrical Power Distribution Plan

4 Electrical Power Distribution Details

5 Electrical Power Distribution Details

6 Electrical Power Distribution Sections

7 Electrical Power Distribution Sections

$\mathrm{H}-2-0090471$

8 Electrical Power Distribution Details

1. Electrical Instm Distribution Plan

$\mathrm{H}-2-0090471$

H-2-00 90472

$\mathrm{H}-2-0090472$

H-2-00 90472

$\mathrm{H}-2-0090472$

$\mathrm{H}-2-0090475$

$\mathrm{H}-2-0090476$

$\mathrm{H}-2-0090476$

$\mathrm{H}-2-0090476$

$\mathrm{H}-2-0090476$

$\mathrm{H}-2-0090476$

$\mathrm{H}-2-0090476$

H-2-00 90476

$\mathrm{H}-2-0090476$

H-2-00 90476

$\mathrm{H}-2-0090476$

H-2-00 90476

$\mathrm{H}-2-0090476$

$\mathrm{H}-2-0090476$

2 Electrical Instm Distribution Sections

1 Electrical Heat Trace Distribution Plan

2. Electrical Heat Trace Distr Plan and Details

3 Electrical Heat Trace Distr Details

4 Electrical Heat Trace Distr Details

2 Elec instr Bldg 241-AP-271 Plan and Elevations

1 Elec Elem Diags Central Exh Station

2 Electrical Elementary Diag Pumps and Fans

3 Electrical Elementary Diagrams Annunciator.

4 Electrical Elementary Diagrams Annunciator

5 Electrical Elementary Diagrams CRT Logic and Controls

6 Electrical Elementary Diagrams Leak Detection Intlks

7 Electrical Elementary Diag CRT Logic

8 Electrical Elementary Diag Leak Detection

9 Electrical Elementary Diagrams Annunciator

10 Electrical Elementary Diagrams Heat Trace

11 Electrical Elementary Diagram Shutdown Ckt \& FA

12 Electrical Elementary Diagrams Radiation Mon

13 Elec Elm Diag Heater Controiler 
HNF-2199, Rev. 0

LISTING OF PRINTS NEEDED FOR TURNOVER

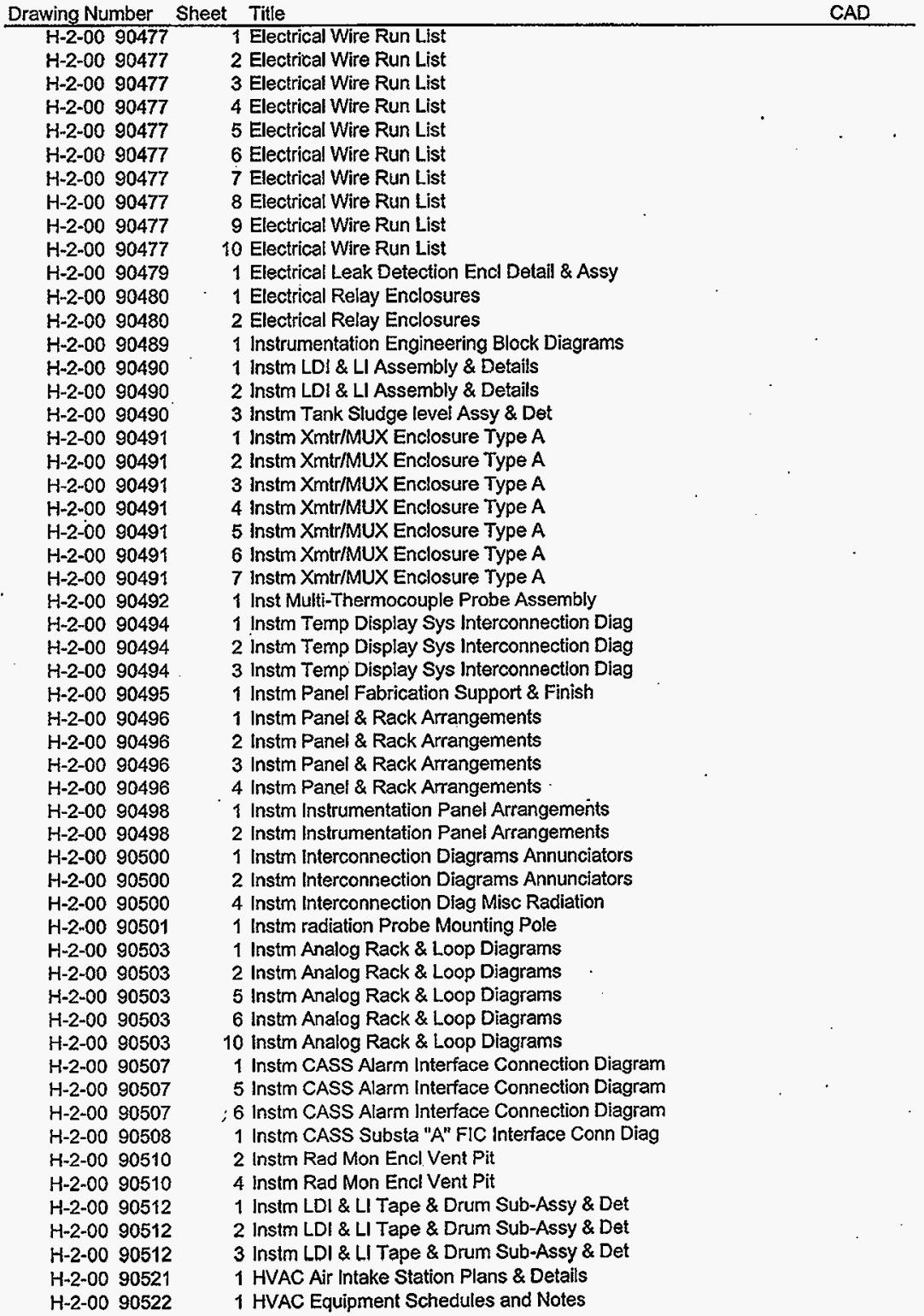


HNFF-2199, Rev, 0

LISTING OF PRINTS NEEDED FOR TURNOVER

Drawing Number sheet Title

H-2-00 90533

$\mathrm{H}-2-0090534$

1 Engineering Flow Diagram 241-AP-106

H-2-00 90536

1 Tank Cross Section 241-AP Tanks

H-2-00 90537

1 Plan Tank Penetrations 241-AP-106 \& 108

H-2-00 90541

1 Tank Penetrations \& Riser Details 241AP Tanks

1 Engineering Flow Diagram 241-AP-108

H-2-00 90542

H-2-00 90543

1 Piping Hydraulic Diagram 241-AP Tank Farm

H-2-00 90544

H-2-00 90547

1 Piping Plan \#1 241-AW Tank Farm

1 Piping Plan \#2 Waste Transfer Lines

H-2-00 90547

1 Piping Plan \#5

H-2-00 $\$ 0548$

2 Piping Plan \#5

H-2-00 90552

1 Piping Plan \#6

H-2-00 90558

1 Piping Sections \& Details 241-AP Tank Farm

$\mathrm{H}-2-0090560$

1 Piping Plan Tank 106

1 Piping Plan Tank 108

H-2-00 90561

H-2.00 90561

1 Piping Miscellaneous Details 1

$\mathrm{H}-2-0090562$

2 Piping Miscellaneous Details I

1 Piping Plan Central Pump Pit 241-AP-01A Thru 08A

H-2-00 90563

1 Piping Sect \& Det Central Pump Pit 241-AP-01A Thru 08A

H-2-00 90564

1 Piping Plan Annulus Pump Pit 241-AP-01B Thru 08B

H-2-00 90565

$\mathrm{H}-2-0090570$

1 Ppg Sect \& Det Annulus Pump Pit 241-AP-018 Thru 08B

H-2-00 90572

$\mathrm{H}-2-0090573$

$\mathrm{H}-2-0090574$

$H-2-0090574$

H-2-00 90576

H-2-00 90582

$\mathrm{H}-2-0090583$

$\mathrm{H}-2-0090585$

$\mathrm{H}-2-0090585$

H-2-00 90585

$\mathrm{H}-2-0090585$

$H-2-0090585$

H-2.00 90586

H-2-00 90586

$\mathrm{H}-2-0090592$

$\mathrm{H}-2-0090594$

H-2-00 90595

$\mathrm{H}-2-0090595$

$\mathrm{H}-2-0090596$

$\mathrm{H}-2-0090599$

H-2-00 90599

$\mathrm{H}-2-0090600$

H-2-00 90725

H-2-00 90726

$\mathrm{H}-2-0090727$

H-2.00 90729

H-2-00 90750

1 Piping Concrete Shielding Details

1 Piping Riser Details 1

1 Piping Riser Details II

1 Piping Riser Details III

2 Piping Riser Details IV

1 Piping Pump Arrangements P-AP-1 \& P-AP-2

1 Piping Support Plan \#5

1 Piping Support Plan \#6

1 Piping Expansion Void Details

2 Piping Expansion Void Details

3 Piping Expansion Void Detalls

4 Piping Expansion Void Details

5 Piping Expansion Void Detalls

1 Piping Exhaust Line End

2 Piping Exhaust Line End

1 Piping Support Plan TK-106

1 Piping Support Plan TK-108

1 Piping Support Details

2 Piping Support Details

1 Pit \& Pit Cover Painting Diag 241-AP Tank Farms

1 Jumper Arrgmt Ct Pump Pit 241-AP-01A Thru 08A

2 Jumper Argmt Ctl Pump Pit 241-AP:01A Thru 08A

1 Jumper Arrgmt Annulus Pump Pit 241-AP-01B Thru 08B

1 Jumper Assembly A-E Pump Central Pump Pit

1 Flex Jumper Assembly A-C, A-D Alternate

1 Jumper Assy $B$ to Distributor Central Pump Pit

1 Flex Jumper Assembly Pump to A

1 HVAC Details

5 Electrical Details

H-2-00 90751

H-2-00 90833

H-2-00 90835

H-2-00 90835

$\mathrm{H}-2.0090841$

H-2-00 90842

$\mathrm{H}-2-0090843$

1 Piping Dummy Pump Head

1 Piping Vent Pit \#1 \& \#2

2 Piping Vent Pit \#1 \& \#2

1 Piping Concrete Shielding

1 Piping Misc Details II

1 Piping Misc Delails IiI 
HNF-2199, Rev. 0

\section{LISTING OF PRINTS NEEDED FOR TURNOVER}

Drawing Number Sheet Tite

CAD

$\mathrm{H}-2-0090844$

$\mathrm{H}-2-0090845$

$\mathrm{H}-2-0090846$

$\mathrm{H}-2-0090848$

$\mathrm{H}-2-0090849$

$\mathrm{H}-2-0090850$

$\mathrm{H}-2-0090852$

$\mathrm{H}-2-0090853$

$\mathrm{H}-2-0090853$

H-2-00 91247

$\mathrm{H} \cdot 2-00 \quad 91550$

$\mathrm{H}-2-0091550$

H-2-00 91760

$\mathrm{H}-2-0091943$

$H-2-0091943$

$\mathrm{H}-2-0091943$

$\mathrm{H}-2-0092447$

H-2-00 92448

H-2-00 92449

H-2-00 92449

H-2-00 92450

H-2-00 92450

$\mathrm{H}-2-0092450$

H-2-00 92451

$\mathrm{H}-2-0092452$

Hi-2-00 92452

$\mathrm{H}-2-0092453$

$\mathrm{H}-2-0092453$

$\mathrm{H}-2-0092488$.

$\mathrm{H}-2-0092488$

$\mathrm{H}-2-00 \quad 92490$

$\mathrm{H}-2-00 \quad 92497$

$\mathrm{H}-2-0092497$

$\mathrm{H}-2-0094082$

H-2-00 94083

H-2-00 94084

H-2-00 94085

$\mathrm{H}-2-0094086$

$\mathrm{H}-2-0094087$

$\mathrm{H}-2-0094872$

H-2-00 94872

$\mathrm{H}-2-0094872$

$\mathrm{H}-2-0095260$

$\mathrm{H}-2-0095260$

$\mathrm{H}-2-0095260$

$\mathrm{H}-2-0095331$

H-2-00 95331

H-2-00 95331

H-2-00 95331

$\mathrm{H}-2.0095331$

H-2-00 95331

H-2-00 95360

$\mathrm{H}-2-0095360$

$\mathrm{H}-2-0095360$

H-2-00 95365
1 Piping Distribitor Assy

1. Jumper Misc Details III

1 Piping Spray Wand Assy

1 Piping Pit Drain Seal Assembly

1 Piping Pit Drain Seal Details

1 Piping Miscellaneous Detalls IV

1 Jumper Misc Details I

1 Jumper Misc Details II

2 Jumper Misc Details II

1 12" Annulus Exhaust Duct Probe Assembly

14 " Drill Rod Guide Assembly and Details

2 4" Drill Rod Guide Assembly and Detalls

1 Dual Beta Monitor Cabinet Split Entry Assy

1 Process Turbine Pump-AN-AW-AP

2 Process Turbine Pump-AN-AW-AP

3 Process Turbine Pump-AN-AW-AP

1 Surveillance P. A. D. Assembly

1 Surveillance P. A. D. Main Amplifier Board Assembly

1 Surveillance P. A. D. Auxiliary Board Schematics

2 Survellance P.A. D. Auxiliary Board Schematics

1 Surveillance P. A. D. Main Amplifier Board Drill \& Trim

2 Surveillance P. A. D. Main Amplifier Board Drill \& Trim

3 Surveillance P. A. D. Main Amplifier Board Drill \& Trim

1 Surveillance P. A. D. Auxiliary Board Assembly

1 Surveillance P. A. D. Low Voltage Auxiliary Board - Silk Screen

2 Surveillance P. A. D. Low Voltage Auxiliary Board - Silk Screen

1 Survellance P. A. D. High Voltage Auxiliary Board - Silk Screen

2 Surveillance P. A. D. High Voltage Auxiliary Board - Silk Screen

1 Generic Stack Sampler / Monitor Modified Monitor Assy

2 Generic Stack Sampler / Monitor Modified Monitor Assy

1 Generic Stack Sampler / Monitor Sample Extraction Assy

1 Generic Stack Sampler / Monitor Basic Cabinet Assy

2 Generic Stack Sampler / Monitor Basic Cabinet Assy

1 Cathodic Protection Piping Plan \#6

1 Cathodic Protection Test Station Details

1 Cathodic Protection Test Station Details

1 Cathodic Protection Details Anodes, Rectifters

1 Cathodic Protection Details Cables, Boxes \& Jumpers

1 Cathodic Protection Details Connections, Miscellaneous

1 Liquid Level Instr. Shielding

2 Liquid Level Instr. Shielding

3 Liquid Level Instr. Shielding

1 Stainless Steel Flake Tank Electrode Box Assy

2 Stainless Steel Flake Tank Electrode Box Assy

3 Stainless Steel Flake Tank Electrode Box Assy

1 Liquid Level Reel Arrangement

2 Liquid Level Reel Arrangement

3 Liquid Level Reel Arrangement

4 Liquid Level Reel Arrangement

5 Liquid Level Reel Arrangement

6 Liquid Level Reel Arrangement

1 Flash Tank

2 Flash Tank

3 Flash Tank

1 Liquid Level Piummet 
HNF-2199, Rev, 0

\section{LISTING OF PRINTS NEEDED FOR TURNOVER}

Drawing Number Sheet Tite

\begin{tabular}{|c|c|c|c|}
\hline$H-7-00$ & 1275 & 1 Electrical Symbol & \\
\hline H-9.00 & 1105 & 1 Pump Vertical-Turbine Non-Corrosive Service & \\
\hline$-14-00$ & 10503 & $\begin{array}{l}\text { Dome Penetration Schedules (WSTMSTA) Tank } \\
6106\end{array}$ & 241-AP- \\
\hline & & Dome Penetration Schedules (WST/WSTA) Tank & 241-AP- \\
\hline$-14-00$ & 10503 & 8108 & \\
\hline$-1-14-00$ & 20000 & 1 Tank Farms System P\&ID Drawing Legend & \\
\hline H-14-00 & 20000 & 2 Tank Farms System P\&ID Drawing Legend & \\
\hline$H-14-00$ & 20103 & 1 Ventilation Tank Primary System (VTP) O\&M Sys & \\
\hline$H-14-00$ & 20203 & 1 Ventilation Tank Annulus System (VTA) O\&M Sys & \\
\hline$H-14-00$ & 20203 & 2 Ventilation Tank Annulus System (VTA) O\&M Sys & \\
\hline$H-14-00$ & 20303 & 1 Service \& Instrumentation Air System (SAIS) O\&N & P\&ID \\
\hline$H-14-00$ & 20303 & 3 Service \& Instrumentation Air System (SAIS) O\&N & P\&ID \\
\hline$H-14-00$ & 20303 & 5 Service \& Instrumentation Air System (SAIS) O\&N & P\&ID \\
\hline$H-14-00$ & 20503 & 6 Waste Storage Tank Annuius Instm Sys (WSTA) C & Sys P\&ID \\
\hline$H-14-00$ & 20503 & 8 Waste Storage Tank Annulus Instm Sys (WSTA) & Sys P\&ID \\
\hline$H-14-00$ & 20603 & 6 Waste Ștorage Tank Primary Instm Sys (WST) O\& & ys P\&ID \\
\hline$H-14-00$ & 20603 & 8 Waste Storage Tank Primary Instm Sys (WST) $O \&$ & ys P\&ID \\
\hline$H-14-00$ & 20803 & 4 Waste Transfer System (WT) O\&M Sys P\&ID & \\
\hline H-14-00 & 21803 & 1 Raw Water System (RW) O\&M Sys P\&ID & \\
\hline$H-14-00$ & 30003 & 1 Electrical (EDS) One Line Diagram & \\
\hline$-14-00$ & 30003 & 2 Electrical (EDS) One Line Diagram & \\
\hline$H-14-00$ & 30003 & 22 Electrical (EDS) Panelboard Schedule & \\
\hline$H-14-00$ & 30003 & 23 Electrical (EDS) Panelboard Schedule & \\
\hline$+14-00$ & 30003 & 27 Electrical (EDS) Panelboard Schedule & \\
\hline H-14-00 & 30003 & 28 Electrical (EDS) Equipment Power Isolation Table & \\
\hline
\end{tabular}

Number of Prints to Convert to $C A D$

Number of Prints to Needed for Turnover 
HNF-2199, Rev. 0

\section{APPENDIX B \\ PROCEDURE DEVELOPMENT CHECKLIST}


HNF-2199, Rev. 0

\section{PROCEDURE DEVELOPMENT CHECKLIST}

The following checklist was developed to help determine which procedures will be impacted by transferring $241-\mathrm{AP}-106$ and $241-\mathrm{AP}-108$ to the vitrification privatization contractors.

1 Does it regulate/infiuence Farm Facility access? (e.g. gates, training requirements, vehicle access, personnel access)

2 Does it regulate/influence Waste Management/Disposal? (e.g. laundry services, waste pick-ups/disposal, use of Satellite Accumulation Area)

3 Does it affect document review/release?

$4 \quad$ Does it affect work release?

$5 \quad$ Does it specify charters?

6 Does it specify real estate?

7 Does it specify contractor responsibilities/roles/interfaces?

8 Does it affect information/technology/documentation transfer/transmittal protocol?

9 Does it affect configuration management? (e.g. drawing release, configuration control, drawing/configuration ownership)

10 Does it affect Conduct of Operations? (e.g. equipment status, lock and tag, event reporting)

11 Does it affect bargaining unit contracts?

12 Does it affect project management protocol/interfaces?

13 Does it affect training program scope/requirements?

14 Does it affect PHMC/contractors ability to accept non-DOE work scope /funding?

15 Does it affect contractual agreements?

16 Does it affect emissions monitoring? (e.g. stack, soil, water)

17 Does it affect emergency response or reporting requirements? 
HNF-2199, Rev. 0

\section{APPENDIX C}

OPERATING PROCEDURES 
HNF-2199, Rev. 0

\section{ÓPERATING PROCEDURES}

\section{Plant Operating Procedures}

TO-001-180

104-AP

TO-001-182

TO-020-005

TO-020-141

TO-020-193

TO-020-270

TO-020-420

TO-020-430

TO-020-595

TRANSFERS

TO-020-755

TO-040-020

TO-040-025

TO-040-035

TO-040-180

T0-040-501

TO-040-540

T0-040-560

TO-040-590

TO-040-650
EMERGENCY TRANSFER FROM TK-101-AY/TK-102-AY TO TK-

EMERGENCY PUMP PROCEDURE FOR AP-FARM

PERFORM PIT EXAMINATIONS

IN-TANK VIDEO PROCEDURE

RESPOND TO LDT-48 ALARMS IN AP TANK FARMS

PREPARATION FOR WORK IN DIVERSION BOXES OR PITS AND JUMPER CHANGES

CLEAN, LIT TAPES, PLUMMETS AND DISPLACERS; REPLACE FIC/ROBERT SHAW TAPES

REMOVE TANK SLUDGE LEVEL WEIGHTS OR MEASUREMENT PENCILS

LEAK DETECTYON PIT/RADIATION DETECTION DRYWELL

RECORD STATUS OF FACILITY ALARM PANELS

OPERATE CASS TERMINAIS

OPERATE CASS CENTRAL FACILITY

OPERATE THE TMAC SURVEILLANCE SYSTEM FOR UGS TANKS

OPERATE TANK SURFACE LEVEL MONITORING DEVICES

PERFORM SURVEILLANCE/SAFETY/HOUSEKEEPING

INSPECTION OF 200-EAST TANK FARMS

RAW WATER SURVEILLANCE AND USAGE

200 EAST/WEST TANK FARMS SLUDGE LEVEL READINGS

LEAK DETECTION WELLS AND ANNULUS LEAK DETECTION SYSTEM

OBTAIN/RECORD DOUBLE-SHELL TANK TEMPERATURE DATA 
HNF-2199, Rev. 0

TO-040-740

TO-060-340

TO-060-341

TO-100-002

TO-100-003

TO-100-010

TO-100-040

TO-100-052

TO-100-053

TO-140-170

TO-220-027

T0-220-096

TO-230-276

TO-270-024

TO-270-040

TO-270-140

TO-270-204

TO-270-226

TO-270-244

T0-270-266

TO-270-256

TO-270-311
PERFORM ROUTINE SURV OF WINTERIZED BLDG EQUIP EAST AREA

OPERATE 241-AP PRIMARY VENTILATION SYSTEM

OPERATE 241-AP ANNULUS VENTILATION SYSTEM

PREPARING AND ISSUING WASTE CONTAINERS

PERFORM CLEAN-UP OF RODENT CONTAMNNATED AREAS

WASTE TRUCK SUPPORT SERVICES

ESTABLISH AND INSPECT ACTIVE AND SATELLITE ACCUMULATION AREA CONTAINERS

PERFORM WASTE GENERATION, SEGREGATION AND ACCUMULATION

PERFORM SAMPLING \& REPACKAGING OF LLW, RMW AND HAZ WASTE

PRESSURE TEST OF PROCESS PIPELINES AND PIPE ENCASEMENT

TRANSFER FROM 244-A TO 101-AN

TRANSFER FROM TK-106-AW TO TK-106-AN

TRANSFER FROM TK-244-A TO TK-101-AN

TRANSFER FROM TK-105-AW TO TK-108-AP

OPERATE 241-AP TEMPERATURE DISPLAY SYSTEM

OPERATE 241-AP-273 AIR COMPRESSOR SYSTEMS

TRANSFER FROM 204-AR TO TK-106-AP

TRANSFER FROM TK-101-AN TO TK-106-AP

TRANSFER FROM 244-A TO TK-106-AP

TRANSFER FROM TK-106-AN TO TK 108-AP

TRANSFER FROM TK-102-AY TO TK-106-AP

TRANSFER FROM ER-311 TO TK-106-AP 
HNF-2199, Rev. 0

TO-270-344

TO-270-826

TO-270-828

TO-430-485
TRANSFER FROM 244-BX TO TK-106-AP

TRANSFER FROM B-PLANT CELL 24 TO TK-106-AP

TRANSFER FROM B-PLANT CELL 24 TO TK-108-AP

CROSS-SITE TRANSFER FROM TK-102-SY TO TK-104-AP

Operator Routine Surveillance.Procedures

TF-OR-A-03

AP, AW TANK FARMS

TF-OR-EF-AP

AP TANK FARM ROUNDS

\section{Alarm Response Pracedures}

ARP-T-271-00106 RESPOND TO PANEL 106 ALARMS AT 271-AP

ARP-T-271-00108 RESPOND TO PANEL 108 ALARMS AT 271-AP

ARP-T-271-AUX RESPOND TO PANEL AUX ALARMS AT 271-AP

ARP-T-271-HVAC RESPOND TO PANEL HVAC ALARMS AT 271-AP

ARP-T-271-RM RESPOND TO PANEL RM ALARMS AT 271-AP

ARP-T-601-AB2 RESPOND TO PANEL AB2 ALARMS AT THE 242-A EVAPORATOR

ARP-T-601-081

RESPOND TO FACEPLATE \# 81 ALARMS AT THE 242-A

EVAPORATOR

ARP-T-601-290

RESPOND TO FACEPLATE \# 290 ALARMS AT THE 242-A

EVAPORATOR

ARP-T-601-295 RESPOND TO FACEPLATE \# 295 ALARMS AT THE 242-A EVAPORATOR .

\section{Preventative Maintenance Procedures}

3-MISC-363

WINTERIZATION/DE-WINTERIZATION EAST TANK FARMS

6-TF-15SAE

APPENDIX AE, 241-AP ANNULUS EXHAUSTER STACK 296-A-41 AIR FLOW TEST DATA SH

$6-T F-155 B$

APPENDIX B, 241-AP TANK EXHAUSTER STACK 296-A-40 AIR FLOW TEST DATA SHEETS 
HNF-2199, Rev. 0

$\begin{array}{ll}\text { 6-TF-156AD } & \begin{array}{l}\text { APPENDIX AD, 241-AP TANK FARM ANNULUS INLET FILTER } \\ \text { AEROSOL TEST DATA SHEET }\end{array} \\ \text { 6-TF-221 } & \text { INSPECTION OF CATHODIC PROTECTION SYSTEM } \\ 6-T F-225 & \text { INSPECTION OF EAST TANK FARM TRANSFORMERS } \\ \text { 6-TF-233 } & \text { OPERATING LOAD CHECK \& THERMAL HEATNG SUREY OF } \\ & \text { THE 241-AP AREA DISTRIBUTI } \\ \text { 6-TF-357ET } & \text { CATHODIC PROTECTION SYSTEM TESTING EAST TANK FARMS } \\ \text { (ET) } & \end{array}$

\section{Functional Test Procedures}

TF-EFT-279-110 PERFORM BUILDING AP-271 RADIATION MONITORING FUNCTIONAL TEST

TF-FT-049-002 PERFORM FOOD INSTRUMENT CORPORATION LIQUID LEVEL GAUGE FUNCTIONAL TEST

TF-FT-049-003 - PERFORM ENRAF FUNCTIONAL TEST

TF-FT-049-004 PERFORM MANUAL TAPE FUNCTIONAL TEST

TF-FT-049-006 PERFORM LEAK DETECTION FUNCTIONAL TEST FOR SUPERNATANT AND SLURRY TRANSFER

TF-FT-279-001 PERFORM DOUBLE SHELL TANK 241-AP PRESSURE FUNCTIONALL TEST

TF-FT-279-008 PERFROM AP DST 101 THROUGH 108 ANNULUS LEAK DETECTION FUNCTIONAL TEST

TF-FT-279-016 PERFORM AP DST 101 THROUGH 108 ANNULUS CAM LEAK DETECTION FUNCTIONAL TEST

TF-ICF-020-001 PERFORM WASTE TANK DOME ELEVATION SURVEYS

\section{Operating Specification Documents}

OSD-T-15I-00007 OPERATING SPECIFICATIONS FOR 241-AN,AP,AW,AY,AZ \& SY TANK FARMS

OSD-T-151-00031 OPERATING SPEFICIATIONS FOR TANK FARM LEAK DETECTION 
HNF-2199, Rev. 0

Criticality Specification Documents

CPS-T-149-00010 WASTE STORAGE IN DOUBLE-SHELL TANKS AND ASSOCIATED EQUTPMENT 
HNF-2199, Rev. 0

APPENDIX D

ADMINISTRATIVE PROCEDURES 
HNF-2199, Rev. 0

\section{ADMINISTRATIVE PROCEDURES}

\section{LEVEL I \& II PROCEDURES}

WHC-CM-1-3, Management Requirements and Procedures

GENERAL MANAGEMENT

$1.1 \quad$ Managing DOE Directives

(HNF-PRO-116)

1.5 Obtaining Conflict of Interest Determinations

(HNF-PRO-165)

1.6 Release of Information to the Public

(HNF-PRO-165)

1.16 Performing Work for Others

(HNF-PRO-106)

1.25 Responding to RL Direction

(HNF-PRO-107)

1.27 Determining Allowable Costs

(HNF-PRO-99)

1.29 Internal Assessments

HNF-PRO-551 (Construction Program)

HNF.PRO-555 (System Configuration Management Plan)

HNF-PRO-556 (Verification and Validation Reports\}

1.31 Managing Data and Information

(HNF-PRO-656)

FNANCIAL AND ADMNISTRATIVE SERVICES

$2.1 \quad$ Authorizing Expenditures

(ENF-PRO-695)

2.16 Processing CM System Procedures

(HNNF-PRO-589)

2.21 Requesting and Processing Waivers to Controlled Manuals (HNF-PRO-589) 
HNF-2199, Rev. 0

INFORMATION RESOURCE MANAGEMENT

3.7 Reproduction Services

3.8 Determining Signature Authority for Official External Correspondence

(HNF-PRO-113)

3.9 Mail Services

(HNF-PRO-698)

3.10 Photography and Audiovisual Services

3.17 Telephone Services

3.20 Celiular Telephone Service

OPERATIONS ASSURANCE

5.10 Waste Management Unit Management

5.12 Identifying and Resolving Unreviewed Safety Questions (See WHC-CM-1-5, 7.3)

5.44 Waste Minimization Program

(See WHC-CM-7-5, 14.0)

TECHNCAL AND OPERATYONAI SERVICES

6.12 Building Management

6.15 Facility Shutdown, Standby, and Transfer

WHC-CM-1-4 Corrective Action Management Manual

(Replaced in its entirety FNF-PRO-052)

WHC-CM-1-5 Standard Operating Practices

1.0 OPERATIONS ORGANIZATION AND ADMINISTRATION

1.2 Startup and Restart of Facilities

(HNF-PRO-55)

2.0 SHIFT ROUTINES AND OPERATING PRACTICES

3.0 CONTROL AREA ACTIVITIES 
HNF-2199, Rev. 0

4.0 COMMUNICATIONS

5.0 CONTROL OF ON-SHIFT TRAINING

5.1 Operational Drill Program

(HNF-PRO-56)

6.0. RVESTIGATION OF ABNORMAL EVENTS

6.2 Critiquing Events

(HNF-PRO-58)

7.0 NOTIFICATIONS

7.1 Reporting Occurrences and Processing Operations Information (FNF-PRO-60)

7.2 Reporting Safety Concerns for NRC Programs/Facilities (HNF-PRO-061)

7.3 Identifying and Resolving Unreviewed Safety Questions (HNF-PRO-062)

8.0 CONTROL OF BQUIPMENT AND SYSTEM STATUS

8.1 Alarm Management

(HNF-PRO-063)

8.2 Tagging Portable Tools and Equipment Out of Commission (HNF-PRO-064)

9.0 LOCKOUTS AND TAGOUT

9.2 Electrical Utilities Lock and Tag Program

(HNF-PRO-66)

10.0 INDEPENDENT VERIFICATION

11.0 LOGKEEPING

12.0 OPERATIONS TURNOVER

13.0 OPERATIONS ASPECTS OF FACILITY CHEMTSTRY AND UNIQUE PROCESSES

14.0 REQUIRED READING

14.1 Managing Lessons Learned

(HNF-PRO-67) 
HNF-2199, Rev, 0

\subsection{TIMELY ORDERS TO OPERATORS}

15.1 Shutdown and Stop-Work Direction

16.0 OPERATIONS PROCEDURES

17.0 OPERATOR AID POSTINGS

18.0 EQUIPMENT AND PIPING LABELING

\section{WHC-CM-1-8 Work Management Manual}

1.0 Fundamentals

(HNE-PRO-69)

2. Work Document Processing

(WHC-IP-1217)

3. Plant Forces Work Review

(HNF-PRO-070)

4. Work Turndown Process

(See WHC-CM-1-3, 4.7)

6. Preparing Excavation Permits

(HNF-PRO-473)

7. Plant Instrumentation and Equipment Status Labeling

(HNF-PRO-072)

\section{WHC-CM-1-10 Safety Manual}

$1 \quad$ Safety Responsibilities

(HNF-PRO-074)

2 Safety Communications

(HNF-PRO-075)

3 Safety Inspection

(HNF-PRO-076)

4 Reporting and Investigating Accidents, Injuries, and IIlnesses (HNF-PRO-077)

5 Subcontractor Safety and Health Management (HNF-PRO-078) 
HNF-2199, Rev. 0

6 Pre-Job Safety Planning (HNF-PRO-079)

$7 \quad$ Worksite First Aid (FNF-PRO-080)

8 Hazardous Energy Control Standard (HNF-PRO-081)

10 Personal Protection (HNF-PRO-083)

11 Safety Showers and Eyewashes (HNF-PRO-084)

12 Hand and Portable Power Tools (HNF-PRO-085)

13 Machine Guarding (HNF-PRO-086)

14 Storing, Using, and Handling Compressed Gases (HNF-PRO-087)

15 Electrical Work Safety (INNF-PRO-088)

16 Electrical Installation Safety (HNF-PRO-089)

17 Excavating, Trenching, and Shoring (FNF-PRO-090)

18 Walking/Working Surfaces (HNF-PRO-091)

19 Fall Protection (HNF-PRO-092)

20 Elevating Work Platforms (HNF-PRO-093)

21 Ladders (HNF-PRO-094)

22 Scaffolding (HNF-PRO-095) 
HNF-2199, Rev. 0

23 Erecting Steel Structures

(HNF-PRO-591)

24 Concrete and Masonry Construction

(HNF-PRO-577)

25 Material Handling and Storage

(HNF-PRO-096)

26 Demolition

(HNF-PRO-576)

27 Transportation Safety

(HNF-PRO-100)

28 Signs, Tags, and Barriers

(HNNF-PRO-101)

29 Safety Color Coding

(HNNF-PRO-102)

30 Control of Working Hours and Working Alone (HNF-PRO-103)

32 Steam Distribution System Safety

(FNNF-PRO-105)

HNF-MD-003 Contractor Identifiers in Controlled Information Product (HNFF-PRO-604)

HNF-MD-006 Identifying/Reporting a DOE Nuclear Safety Requirement Noncompliance

WHC-CM-1-11 Industrial Hygiene Manual

WKH-1 Industrial Hygiene Program Overview

WKH-2 Asbestos Control

WKH-4 Carcinogen Control

WKHE-5 Confined Space Program

(HNNF-PRO-110)

-WKiH-6 Occupational Medical Qualification and Monitoring

(HNF-PRO-111)

WKHH-8

Hazard Communication 
HNF-2199, Rev. 0

WKH-9 Hazardous Waste Operations \& Emergency Response

WKH-11 Process Safety

WKH-14 Lead Control Program

. (HNF-PRO-119)

WKH-17 Industrial Hygiene Records Management

WHC-CM-2-3 Property Management Manual

4.3 Reporting Loss/Damage/Destruction of Government-Owned Property (HNF-PRO-137)

7.5 Transfer of Property to Other Hanford Contractors

(HNF-PRO-146)

7.7 Disposition of Non-Capitol Equipment Used in Radiation Zones

8.1 Management of Government-Owned Property in the Possession of Subcontractors and Vendors

(HNF-PRO-150)

9.1 Property Management Walkthroughs (FNF-PRO-374)

WHC-CM-2-5 Management Control System

HNF-MD-008 Baseline Change Control

HNF-MD-013 Work Breakdown Structure

HNF-MD-015 Cost Account Plan

HNF-MD-017 Multi-Year.Work Plan

HNF-MD-019 Project Work Authorization

HNF-MD-022 Incoming External Work Orders

HNF-MD-023 Work for Others

1.0 DEFINE AND ORGANZE WORK

1.1 Work Breakdown Structure, Index and Dictionary (HNF-PRO-518) 
HNF-2199, Rev. 0

2.0 PLANNING AND WORK ORGANIZATION

2.1 Cost Account Authorization

(HNF-PRO-521)

2.2 Cost Account Plan

(HNF-PRO-522)

2.3 Baseline Management

(UNNF-PRO-523)

2.4 Funds Management

(ENF-PRO-524)

2.5 External Work Orders

(HNF-PRO-525)

2.8 Capital Equipment Not Related to Construction

(HNF-PRO-526)

\subsection{REPORTING}

3.1 Data Analysis and Variance Reporting

(HNF-PRO-527)

Appendix A, Cost Performance Analysis and Trend Analysis Techniques

Appendix B, Variance Analysis Report, Form and Preparation Instructions

Appendix C, Financial Data System Reports

3.2 Estimates at Completion

(HNF-PRO-528)

3.3 Agreements, Commitments and Action Items

3.4 Project Reporting

(HNF-PRO-529)

3.5 Site Management System Reporting (HNF-PRO-530)

4.1 Change Control

(HNF-PRO-533) 
HNF-2199, Rev. 0

\subsection{SURVEILLANCE}

5.1 Surveillance

(FNF-PRO-534)

5.2 Associate Contractors

5.3 Acceptance Review

(HNF-PRO-535)

\subsection{REFERENCE MATERIAL}

Appendix A, Glossary and Acronym List.

(ENF-PRO-536)

\section{WHC-CM-2-14 Hazardous Material Packaging and Shipping}

PART I Introduction

(HNF-PRO-152)

PART II : Responsibilities and Procedures for all Hazardous Material Shipments (EENF-PRO-154)

PART III Nonradioactive Hazardous Materials/Hazardous Waste (HM/HW)

Shipments

(HNF-PRO-156)

PART IV Radioactive Material Shipments

(FNF-PRO-157)

PART V Shipping and Receiving Hazardous Material in the 1100 Area

(HNF-PRO-158)

PART VI Cargo Tanks/Cargo Tank Motor Vehicles

(HNF-PRO-160)

PART VII Documentation and Record Keeping

(HNF-PRO-163)

PART VIII Transportation Safety Training Requirements

(HNF-PRO-166).

\section{APPENDIXES}

D1. Prenotification Requirements for Offsite Shipments of Spent Fuel and High Level Radioactive Waste

D2. Prenotification Requirements for Offsite Shipments of Highway Route Controlled Quantities of Radioactive Materials 
HNF-2199, Rev. 0

\section{WHC-CM-2-15 Training Standards}

\section{EXECUTIVE SUMMARY}

1.0 SYSTEMATIC APPROACH TO TRAINING

1.1 Using the SAT Model for Training

(HNF-PRO-167)

2.0 TRAINING ORGANIZATION

\subsection{Employee Training}

(HNF-PRO-168)

2.2 Assigning Training Responsibilities

(HNF-PRO-169)

\subsection{TRAINING ANALYSIS}

3.1 Analyzing Training Requirements

(HNF-PRO-170)

4.0 TRAINING DESIGN

4.1 Designing Training (HNF-PRO-171)

5.0 TRAINING DEVELOPMENT

5.1 Developing Training (HNF-PRO-172)

6.0 TRAINING IMPLEMENTATION

6.1 Implementing Training (HNF-PRO-173)

7.0 TRAINING EVALUATION

7.1 Evaluating Training (HNF-PRO-174)

8.0 QUALIFICATION PROGRAMS

8.1 Developing a Qualification Program (ANF-PRO-175)

8.2 Preparing Qualification Programs at Nuclear Facilities (HNF-PRO-176) 
FNF-2199, Rev. 0

8.3 Preparing Certification Programs at Nuclear Facilities (HNF-PRO-177)

8.4 Qualifying Instructional Staff (HNF-PRO-178)

HNF-PRO-249 (Training Course Administration and Records)

\subsection{PROCEDURES}

9.1 Obtaining Training Exceptions and Extensions (HNF-PRO-179)

\section{WHC-CM-3-4 Information Release Administration}

IRA-1.1 Introduction

(HNF-PRO-184)

IRA-1.4 Use of References

(HNF-PRO-185)

IRA-1.5 Information Release Forms

(HNF-PRO-187)

IRA-1.6 Processing Business-Sensitive Information

(HNF-PRO-188)

IRA-2.1 Public Release: New Documents, Full Revisions, Changes (HNF-PRO-189)

IRA-2.2 Pre-Consolidation Documents

(HNF-PRO-191)

IRA-2.6 Computer Software

(HNF-PRO-199)

IRA-3.1 Limited Distribution Documents

(HNF-PRO-201)

IRA-4.1 Uncontrolled General and Administrative

(HNF-PRO-203)

IRA-5.2 Outside Requests

(HNF-PRO-206) 
HNF-2199, Rev. 0

\section{WHC-CM-3-5 Document Control and Record Management Manual}

1.0 General

(HNF-PRO-208)

1.1 Performing Management Implementation Reviews

(HNF-PRO-209)

1.2 Records Management Program

(HNF-PRO-210)

1.3 Administrative Record

(HNF-PRO-211)

4.0 Records Inventory and Disposition Schedules

(HNF-PRO-214)

5.0 Records Storage, Retrieval, and Destruction

(ENF-PRO-215)

6.0 Vital Records Protection Program

(HNF-PRO-216)

8.4 Other Records Management Activities, File Equipment Procurement

(HNF-PRO-221)

9.0 Quality Assurance Records

(HNF-PRO-222)

12.0 Document Control

(HNF-PRO-224)

12.2 Classified Document Control

(HNF-PRO-226)

12.3 Micrographics/Vault Services

(HNF-PRO-027)

12.4 Central Files and Distribution of Non-Copy-Controlled Documents

(HNF-PRO-228)

12.5 Technical Procedure Standard

(HNF-PRO-229)

12.7 Approval of Environmental, Safety and Quality Affecting Documents (HNF-PRO-233)

12.8 Controlling Field, Laboratory, and Facility Notebooks/Logbooks

(HNF-PRO-230) 
HNF-2199, Rev. 0

12.9 Correspondence and Commitment Control (HNF-PRO-231)

12.10 Project and Task Document Management (HNF-PRO-232)

WHC-CM-4-2 Quality Assurance Manual

QR 1.0 ORGANIZATION

(HNF-MP-599)

QR 2.0 QUALITY ASSURANCE PROGRAM

(HNE-MP-599; HNF-PRO-232 \& HNF-PRO-053)

Q1 2.1 Quality Assurance Program Planning - Project Type Activities (HNF-PRO-261)

QI 2.4 Qualification and Certification of Inspection and Test Personnel. (HNF-PRO-263)

QR 10.0 INSPECTION AND SURVEILLANCE (HNF-MP-599)

QR 12.0 CONTROL OF INSTRUMENTS

(HNF-MP-599)

QI 12.2 Operator Calibrated Measuring and Test Equipment

QI 12.3 Calibration Control of Plant-Installed Instrumentation

QI 12.4 Calibration Control of Measuring and Test Equipment

QI 12.5 Statistically Controlled Analytical Instruments

QI 12.6 Determinately Controlled Laboratory Instruments

QI 13.4 Chain-of-Custody for Samples of Environmental Media and Wastes

QR 15.0 CONTROL OF NONCONFORMING ITEMS

(HNF-MP-599)

QI 15.1 Nonconforming Item Reporting

(HNF-PRO-298)

Q1 15.2 Nonconformance Report Processing

(HNF-PRO-298) 
HNF-2199, Rev. 0

QI 15.6 Control of SuspectCounterfeit Items

(HNF-PRO-301)

QR 18.0 INDEPENDENT ASSESSMENTS

(ENE-MP-599; HNF-PRO-246 \& HNF-PRO-651)

WHC-CM-4-27 Radiological Control Practices and Procedures

1.0 GENERAL ADMINISTRATIVE

1.2 Preparing, Reviewing, and Approving Completed Decision Making Packages (FNN-PRO-315)

1.3 Using the Radiological Control Interpretive Authority Process

(HNF-PRO-316)

1.5 Radiological Control Lessons Learned Program

(HNN-PRO-318)

1.6 Performing Radiological Control Self-Assessments

(HNF-PRO-319)

2.11 Using Dosimetry During Tours

(HNF-PRO-322)

\subsection{TRAINING}

5.1 Performing Radiological Training

(HNF-PRO-329)

5.2 Training and Qualifying Radiological Control Technicians

(HNF-PRO-386)

\section{WHC-CM-4-29 Nuclear Criticality Safety Manual}

1.0 General Requirements

(ENF-PRO-334)

2.0 Criticality Safety Control of Fissionable Material

(HNF-PRO-537)

3.0 Nuclear Criticality Safety Training

(HNF-PRO-538)

4.0 Criticality Safety Evaluation

(HNF-PRO-539) 
5.0 Criticality Prevention Specifications

(HNF-PRO-540)

6.0 Criticality Safety Postings

(HNF-PRO-541)

7.0 Labeling Fissionable Material

(HNF-PRO-542)

8.0 Fissionable Material Storage

(FNF-PRO-543)

9.0 Plant Configuration Control

(HNF-PRO-544)

10 Fissionable Material Packaging and Transportation (HNF-PRO-545)

11 Criticality Alarm System

(HNF-PRO-546)

12 Criticality Accident Dosimeters

(See WHC-CM-4-14, PNL-MA-568, PNL-MA-583)

13 Criticality Safety for Firefighting

(HNF-PRO-547)

14 Inspections and Assessments

(HNN-PRO-548)

15 Recovery from Criticality Safety Nonconformance (HNF-PRO-549)

16 Responding to a Criticality or Potential Criticality

(HNF-PRO-550)

\section{WHC-CM-4-33 Security Manual}

1.0 PERSONNEL SECURITY

1.1 Pre-Employment Investigation Program

(HNF-PRO-366)

1.2 Processing Security Clearances and Reporting, Required Information (HNF-PRO-389)

1.3 Special Access Authorization

(HNF-PRO-412) 
HNF-2199, Rev. 0

1.5 Security Badges

(HNF-PRO-412)

1.6 Escorting

(HNF-PRO-390)

1.7 Controlling Site Visits and Tours

(HNF-PRO-413)

1.9 Issuing and.Controlling Building-Specific Security Badges

(HNF-PRO-391)

1.11 Hosting and Escorting Unclassified Foreign National Visitors and Assignees (HNF-PRO-392)

1.12 Obtaining a Private Vehicle Pass

(HNF-PRO-415)

\subsection{SECURITY OPERATIONS}

2.1 Reporting Security Incidents

(HNF-PRO-416)

2.4 Controlling Security Locks and Keys

(HNF-PRO-393)

2.7 Controlling Prohibited Articles

(HNF-PRO-417)

2.10 Physical Protection of Property and Facilities

(FNF-PRO-394)

2.11 Removal of Non-Inspective Material (HNF-PRO-395)

2.13 Use of Explosives on Hanford Site (HNF.PRO-336)

2.16 Reporting Foreign Travel

(HNF-PRO-418)

2.17 Security Awareness and Education (HNF-PRO-397)

2.18 Obtaining Special Medical Access Authorization

(HNF-PRO-398)

2.19 Requesting Access to the Patrol Academy Surface Danger Zone (HNF-PRO-399) 
HNF-2199, Rev. 0

\subsection{INFORMATION SECURITY}

3.1 Classified Computer Security

(HNF-PRO-400)

3.3 Reporting Classified Computer Security Incident

(HNF-PRO-401)

3.10 Telecommunications Security

(HNF-PRO-403)

3.12 Classified Work for Others

(HNF-PRO-404)

3.13 Protecting and Controlling Classified Matter

(FNF-PRO-405)

\subsection{SECURITY SYSTEMS MAINTENANCE}

5.0 SITE SAFEGUARDS AND SECURITY PROGRAM PLANNNG

5.1 Site Safeguards and Security Program Planning Requirements (HNF-PRO-427)

\section{WHC-CM-4-40 Industrial Hygiene Manual}

\section{SECTION 1 - INDUSTRIAL HYGIENE PROGRAM}

1.1 Industrial Hygiene Program Overview

1.2 Hazard Assessment and Control

1.3 Medical and Exposure Records

1.4 Training

\section{SECTION 2 - CHEMICAL HAZARDS}

2.1 Hazard Communication Program (HNF-PRO-578)

2.2 Carcinogen Control Program (HNF-PRO-579)

2.3 Asbestos Control Program

2.4 Storing and Handling Chemicals (HNF-PRO-699) 
HNF-2199, Rev. 0

2.6 Process Safety Management

(HNF-PRO-580)

2.7 Chemical Spills and Releases

2.15 Lead

2.16 Pesticides

2.18 Laboratory Safety

(HNF-PRO-587)

2.19 Health and Safety for Hazardous Waste Field Operations (HNF-PRO-599)

Appendix A - Acronyms and Abbreviations

Appendix B - Health and Safety Program Guidance

Appendix C - Site Characterization and Analysis Guidance

Appendix D - Site Control Guidance

Appendix E - Training Guidance

Appendix F - Medical Surveillance Guidance

Appendix G - Employee Protection Guidance

Appendix H - Monitoring Guidance

Appendix I - Information Programs Guidance

Appendix J - Drum and Container Handling Guidance

Appendix K - Decontamination Guidance

Appendix L - Emergency Response Guidance

Appendix M - Illumination Guidance

Appendix N - Sanitation Guidance

Appendix O - New Technology Program Guidance

Appendix P - References

2.20 Hazardous Waste Operations at RCRA TSD Facilities (HNE-PRO-599)

D-18 
HNF-2199, Rev, 0

2.21 Hazardous Waste Operations Emergency Response

(HNF-PRO-599)

SECTION 3 - PHYSICAL HAZARDS

3.1 Confined Space Entry

(See WHC-CM-1-11)

3.3 Human Factors

3.4 Temperature Extremes

(See WHC-CM-1-11)

3.5 Noise/Hearing Conservation

(See WHC-CM-1-11, WKH-10)

3.6 Ventilation

3.7 Using Nonionizing Radiation Sources

(HNF-PRO-582)

3.8 Using Lasers

(HINF-PRO-583)

3.9 Illumination

SECTION 4 - BIOLOGICAL HAZARDS

4.1 Occupational Exposure to Bloodborne Pathogens (HNN-PRO-584)

4.2 Indoor Air Quality

4.3 Drinking Water Quality

4.4 Sanitation

SECTION 5 - PROTECTIVE EQUIPMENT

5.2 Respiratory Protection Standard

(See WHC-CM-1-11, WKH 15)

5.3 Respiratory Protection Manual

(See WHC-CM-1-11, WKF 15)

WHC-CM-4-41 Fire Protection Program Manual

SECTION 1 - FIRE PROTECTION PROGRAM 
HNF-2199, Rev. 0

1.1 Fire Protection Program Overview

(FINF-PRO-340)

1.2 Fire Protection Policy Statement

(HNF-PRO-341)

1.3 Responsibilities

(HNF-PRO-342)

SECTION 2 - MANAGEMENT AND ADMINISTRATION

2.1 Exemptions and Equivalencies

(HNNF-PRO-344)

2.2 Fire Protection Corrective Actions

(HNF-PRO-345)

2.4 Fire Protection in Facility Operating Procedures

(HNF-PRO-346)

2.6 Employee Fire Protection Training

(HNF-PRO-347)

2.7 Fire Protection Records

(HNF-PRO-348)

SECTION 3 - FIRE PROTECTION DESIGN

3.1 Fire Protection Design Criteria

(FNF-PRO-349)

3.4 Fire Hazard Analysis Requirements

(HNF-PRO-350)

SECTION 4 - FIRE PROTECTION SYSTEMS

4.2 System Testing/Inspecting and Maintenance Frequencies

(FNN-PRO-351)

4.3 Fire Protection System Discrepancies

(HNF-PRO-352)

4.4 Fire Protection System Winterization

(HNF-PRO-353)

SECTION 5 - FIRE PREVENTION PROCEDURES

5.1 Fire Watch Requirements

(HNF-PRO-354) 


\subsection{Portable Heaters}

(HNF-PRO-355)

5.3 Controlling Hotwork

(HNV-PRO-356)

5.5 Flammable/Combustible Liquids

(HNF -PRO-358)

5.6 Control of Combustibles

(ENF-PRO-359)

5.8 Construction Sites

(HNF-PRO-360)

SECTION 6 - FIRE PROTECTION PROCEDURES

6.1 Portable Fire Extinguishers

(HNF-PRO-361)

6.2 Nonemergency Use of Fire Hydrants

(HNF-PRO-362)

6.3 Building Emergency Exits

(HNF-PRO-363)

6.5 Fire Barriers

(HNN-PRO-365)

SECTION 7 - SPECIAL HAZARDS PROTECTION PROCEDURES

7.3 Oxidizing Materials

(HNF-PRO-367)

7.6 Laboratories

(FNNF-PRO-368)

7.7 Pyrophoric Matexials

(HNF-PRO-369)

7.9 Hazardous Material Storage

(HNF-PRO-370)

7.13 Disposal of Waste Absorbent Material

(HNF-PRO-371) 
HNF-2199, Rev. 0

\section{SECTION 8 - HANFORD FIRE DEPARTMENT}

8.1 Hanford Fire Department

(HNF-PRO-372)

8.2 Hanford Fire Department Coordination Requirements

(FNF-PRO-373)

WHC-CM-4-43 Emergency Management Procedures

(DOE 0223 (Intranet))

(HNF-PRO-424)

\section{WHC-CM-4-46 Safety Analysis Manual}

\section{WHC-CM-6-1 Standard Engineering Practices}

EP-1.2 Specification Requirements

(HNN-PRO-241)

EP-1.3 Engineering Drawing Requirements

(HNF-PRO-242)

EP-1.5 Interface Control Requirements

(HNF-PRO-243)

EP-1.6 Engineering Data Transmittal Requirements (FNNF-PRO-244)

EP-1.7 Engineering Document Approval and Release Requirements (HNNF-PRO-317)

EP-1.12 Supporting Document Requirements (HNF-PRO-439)

EP-2.2 Document Change Control Requirements

(HNF-PRO-440)

EP-2.4 Development Control Requirements

(HNF-PRO-441)

EP-3.3 Vendor Information Requirements

(HNF-PRO-444)

EP-4.2 Testing Requirements

(HNF-PRO-446) 
HNF-2199, Rev. 0

EP-5.3 Interim Design Authority/Design Agent Engineering Process Requirements (HNF-PRO-448)

\section{WHC-CM-6-2 Project Management}

\section{WHC-CM-7-5 Environmental Compliance}

2.0 Air Quality

(FNF-PRO-450)

3.0 Regulated Substance Management

(ENNF-PRO-451)

4.0 National Environmental Policy Act/State Environmental Policy Act (HNF-PRO-452)

5.0 Records, Reporting and Response Activities

(HNF-PRO-453)

7.0 Solid Waste Management

(HNF-PRO-455)

8.0 Water Quality

(HNF-PRO-456)

9.0 New and Modified Facilities

(HNF-PRO-457)

10.0 Regulatory Permitting

(HNF-PRO-450, 455, \& 456)

11.0 Environmental Training

(HNF-PRO-459)

12.0 Preservation of Cultural and Natural Resources

13.0 Environmental Issue Identification, Review, and Interface Requirements

(HNNF-PRO-461)

14.0 Pollution Prevention

(HNF-PRO-462)

\section{APPENDIXES}

B Environmental Statutes, Regulations and Orders Environmental to Westinghouse Hanford Company 
HNF-2199, Rev. 0

(HNF-PRO-690)

C Derived Concentration Guides

(HNF-PRO-690)

D Maximum Contaminant Levels

E Compliance Agreements and Consent Orders (HNF-PRO-468)

H NEPA Site-Wide Categorical Exclusions (SWCX)

I Westinghouse Hanford Company RCRA Contingency Planning Program (HNF-PRO-692)

\section{WHC-CM-8-7 Operations Support Services}

100 CHARTERS

200 DIRECTIVES

220 Cold Weather Protection (HNF-PRO-472)

300 MANUALS, PROCEDURES, AND INSTRUCTIONS

503 SPECIAL PERMITS

503.1 Performing Excavation Activities (FNF-PRO-473)

503.2 Core Drilling/Tie-In Permit (HNF-PRO-474)

600 TRANNING

700 SITE SERVICES

720 Electric Service Request (HNF-PRO-478)

721 Pole Contact Permits (HNF-PRO-479)

723 Hanford Site Highway Corridor (HNF-PRO-480)

724 Electrical Utilities Interface Agreement with Facilities/Plants (HNF-PRO-481) 
HNF-2199, Rev. 0

731 Controlling Cross Connection

(HNF-PRO-482)

751 Repair of ASME-Coded Pressure Systems

(HNF-PRO-488)

762 Control of Abrasive Devices

906 Road and Traffic Systems

(HNF-PRO-493)

LEVEL MO PROCEDURES

WHC-CM-2-4 Property and Inventory Accounting Manual

WHC-CM-4-5 Quality Assurance Qualifications and Instructions

WHC-CM-4-14 Applied Radiological Controls

WHC-CM-4-35 Safeguards and Security

1.5 Response Plan-Investigation of Confirmatory Measurements which Fail Acceptance (HNF-PRO-606)

1.6 Conducting Special Inventories following Emergency Evacuations of SNM Facilities (HNF-PRO-607)

WHC-CM-4-50 Safeguards Accounting Manual

WHC-CM-4-55 Patrol Policies, Procedures; and Training

WHC-CM-6-49 TWRS Environmental Compliance Self Assessment Program Manual

WHC-CM-7-4 Operational Environmental Monitoring

WHC-CM-7-7 Environmental Investigations and Site Characterization Manual 
HNE-2199, Rev. 0

WHC-CM-7-8 Environmental Activities

HNF-IP-0030 Fire Protection

FP-2.3 Fire Protection Facility Assessment

(HNF-PRO-684)

FP-2.4 Fire Protection Program Assessment

(HNF-PRO-685)

HNF-IP-0541 Emergency Assignment Roster and Phone Lists

HNF-IP-0718 General Emergency Radiological Recovery Checklists (HNF-PRO-661)

HNF-rP-0718 Health Physica Techincal Practicies and Procedures

PART 1

6.1 Release Surveys

(HNF-PRO-677)

7.1 Survey Method for Reposting Outdoor Contamination Areas (HNF-PRO-678)

PART 2

3.1.11 Radiological Survey Report (HNF-PRO-679)

APP 1

2.1 Establishment of Personnel Dose Rates (HNF-PRO-682)

5.1 Scheduled Radiation Survey Report

(HNF-PRO-683)

PART 11.1 OFFSITE RADIATION SURVEYS (HNF-PRO-687)

HNF-IP-1037 Operations Security - All sections (HNF-PRO-500)

HNF-IP-1041 Training \& Qualification

(HNF-PRO-494) 
HNF-2199, Rev. 0

HNF-IP-1043 Radiation Protection

(HNF-PRO-506)

HNF-IP-1184 Training and Qnalifications

1-1 HGET

(ENTF-PRO-057)

1-2 Environmental Safety and Training

(FNF-PRO-059)

1-3 Environmental Training

(HNF-PRO-065)

1-5 Radiological Control Technician Training

(HNF-PRO-071)

1-6 Radiological Worker Training

(HNF-PRO-082)

1-7 Instructional Staff Training and Qualification (HNF-PRO-118)

1-8 Nuclear Process Operator Training Program

(ENF-PRO-153)

1-9 Operations Management Fundamentals Training Program

(HNF-PRO-155)

1-10 ALARA Program Description (HNF-PRO-159)

1-11 Criticality Safety Training Program Description

(HNF.PRO-161)

3-1 Training Matrix Capabilities \& Access

(HNF-PRO-164)

3-2 Training Scheduling and Registration

(HNE-PRO-247)

3-3 Training Course Administration \& Records

(HNF-PRO-249)

HNF-IP-1244 Radiological Control Document Dev \& Control (HNF-PRO-507 \& 508) 
HNF-2199, Rev. 0

HNF-IP-1246

Radiological Control Support Practices and Procedures

SP-1145 Flour Daniel Hanford Radiation Protection Program Implementation of Title 10, Code of Federal Regulations, Part 835 (HNF-PRO-658)

HNF-MP-001 Management and Integration Plar

HNF-MP-003 Integrated Safety Management System

HNF-MP-004 Safeguards and Security Plan

HNF-MP-005 Risk Management Plan

HNF-MP-007 . Systems Engineering Management Plan

HNF-MP-009 Information Resource Management Plan

HNF-MP-011 Sitewide Qualification and Training Plan

HNF-MP-012 Integrated Hanford Communication Plan

HNF-MP-013 Configuration Management Plan

HNF-MP-014 Quality Assurance Plan

HNF-MP-015 Requirements Management Plan

HNF-PRO-52 Corrective Action Management

HNF-PRO-70 Plant Forces Work Review (Oavis-Bacon Act Compliance)

HNF-PRO-149 Utilities Water Application/Metering for Services 
HNF-2199, Rev. 0

HNF-PRO-246 Management Assessment

HNF-PRO-283 Coutrol of Inspections

FINF-PRO-265 Developing and Maintaining S/RIDS

HNF-PRO-408 Asbestos General Industry - Facility Management

HNF-PRO-409 Exposure Monitoring, Reporting, and Exposure Records Management

HNF-PRO-419 Techuical Issues Management List Procedure

HNF-PRO-428 Hanford Site Technical Baseline Change Control

HNF-PRO-602 Radiation Protection Center of Expertise Operations

HNF-PRO-603 Roles and Responsibilities of the Radiation Protection Center of Expertise

HNF-PRO-653 Deficiency Tracking System

HNF-PRO-655 Environmental QA Programs

HNE-PRO-688 External Dosimetry Investigations

HNF-PRO-700 Safety Analysis \& Technical Safety Requirements

HNF-PRO-701 Safety Analysis Process - Existing Facility

HNF-PRO-702 Safety Analysis Process - Facility Change or Modification

HNF-PRO-704 Hazard and Accident Analysis Process 
HNF-2199, Rev. 0

HNE-PRO-708 Stop Work

HNF-PRO-709 Preparation and Control Requirements for Engineering Drawings

HNF-YP-0842 TWRS Admininstrative Manual

SD-WM-TR-026 Dangerous Waste Training Plan

SD-WM-IP-0974 Dangerous Waste Training Matrices 
HNF-2199, Rev. 0

APPENDLX E

CALIBRATION DATASHEETS REQUIRING MODIFICATIONS 
HNF-2199, Rev. 0

\section{CAIIBRATION DATASHEETS REQUTRNG MODIFICATIONS}

Component Number

A-40-106-TK-PSYCH

A-40-108-TK-PSYCH

A-41-106-ANN-PSYCH

A-41-108-ANN-PSYCH

Al-106-1-AP

AI-108-1

AI-106-2-AP

Al-108-2-AP

AP241-VTA-FLT-222

AP241-VTA-FLT-232

AP904-WSTA-CAM-106

AP904-WSTA-CAM-108

AY-AP-C

AY-AP-D

C8-S48

CVT-106-AP-1

CVT-108-AP-1

DPA-K2-10

DPA-K2 $=13$

DPA-K2-14

DPA-K2-9

DPI-106-1-AP

DPI-106-2-AP

DPI-108-1

DPI-108-2

DPIS-10-6

DPIS-13-5

DPIS-14-6

DPIS-9-5

EN-RECT-301

EN-RECT-302

FA-106-AP-1

FA-108-AP-1

FAS-106-AP-A

FAS-108-AP-1

FI-106-1-AP

FI-106-2(AP)

FI-106-3-AP

FI-106-4-AP

FI-106-5(AP)

FI-106-6(AP)

FI-108-1

FI-108-2

FI-108-3

FI-108-4

FI-108-5

F[-108-6

HTA-AP-1

HTA-AP-2

HTTC-STA-C-1
Activity Title

241-AP 106 TK PSYCH

241-AP 108 TK PSYCH

241-AP 106 ANN PSYCH

241-AP 108 ANN PSYCH

SUPERNATANT PUMP AMMETER

SUPERNATANT PUMP AMMETER

SUPERNATANT PUMP AMMETER

SUPERNATANT PUMP AMMETER

105/106 ANN INLT FLT K2-4-3

107/108 ANN INLT FLT K2-4-4

TK 241AP 106 ANNN EXH CAM

TK 241AP 108 ANN EXH CAM

AMPERAGE TO VOLTAGE CONVRTR

AMPERAGE TO VOLTAGE CONVRTR

241-AP SUB STA INSP \& MAINT

RAN 106-1 INPUT CONVERTER MV/V

RAN 108-1 INPUT CONVERTER NV/N

INTAKE STATION D HEPA DP ALARM

INTAKE STATION C PREFILTER DP

INTAKE STATION D PREFIE TER DP

INTK HEPA K2-4-3 DP ALRM STA C

TK-106-AP PRESSURE INDICATOR

TK-106-AP ANNULUS PRESSURE-STA

TK-108-AP PRESSURE INDICATOR

TK-108-AP ANN PRESS IND-STACTC

INTAKE STATION D HEPA DP INDIC

INTAKE STATION C PREFILTER DP

INTAKE STATION D PREFILTER DP

IN HEPA K2-4-3 DP INDISW STA C

241AP CATH. PROT RECT RI

241AP CATH. PROT RECT R2

TK-106-AP ANNULUS CAM LOW FLOW

TK-108-AP ANNULUS CAM LOW FLOW

TANK 106-AP ANNULUS CAM LOW FL

TANK 108-AP ANNULUS CAM LOW FL

PURGE AIR ROTOMETER

FLOW INDICATOR

FLOW TRANSMITTER

FLOW INDICATOR

FLOW INDICATOR

FLOW INDICATOR

PURGE AIR ROTOMETER

FLOW INDICATOR

FLOW INDICATOR

FLOW INDICATOR

FLOW INDICATOR

FLOW INDICATOR

241-AP COMMON HEAT TRACE TROUB

241AP COMMON HEAT TRACE TROUBL.

INTAKE STA C HEAT TRACE CONTRO 


\section{CALIBRATION DATASHEETS REQUIRING MODIFICATIONS}

Compenent Number

HTTC-STA-D-1

DSULATION/LAGGNG(AP/AW)

LA-106-1(AP115-2)

LA-108-1

LAM-106-1

LAM-108-1

LDA-A-1

LDA-A-2

LDA-B-1

LDA-B-2

LDE-06A(AP173-1)

LDE-06B-1-AP

LDE-08A

LDE-08B-1

LDE-106-2

LDI-106-2(API40-2)

LDI-106-3(AP141-2)

CDI-106-4(AP142-2)

LDI-108-2

LDI-108-3

LDI-108-4

LDXA-A-1

LDXA-B-1

LE-06B-. 1

LE-08B-1

LE-106-1

LE-106-2(AP115-1)

LE-106-3(AP123-1)

LE-108-1

LE-108-2

LE-108-3

LI-106-1

LI-108-1

LIT-106-1(AP107-2)

LIT-108-1

LXA-106-1

LXA-108-1

LXA-B-1

MS-106-1-AP

Ms-108-1

N/A(241AP)

$\mathrm{N} / \mathrm{A}(241 \mathrm{AP})$

N/A(241AP)

PA-106-1(AP006-9)

PA-106-2(AP006-8)

PA-108-1

PA-108-2

PA-A-1

PA-A-2

PAS-106-1-AP

PAS-106-2-AP
Activity Title

INTAKE STA D HEAT TRACE CONTRO

241-AP/AW ANNUAL INSPECTION OF

TK-106-AP HIGH LIQ LEVEL ALARM

TK-108-AP HIGH LL ALARM

P-106-1 CURRENT LIMIT ALARM MO

P.108-1 CUPPENT LIMIT ALARM MO

COMMON LEAK DETECTION ALARM-CE

COMMON LEAK DETECTION ALARM-CE

COMMON LEAK DETECTION ALARM-AN

COMMON LEAK DETECTION ALARM-AN

CENTRAI PUMP PIT LEAK DETECTIO

ANNULUS PUMP PIT LEAK DETECTIO

CENTRAL PUMP PIT LEAK DETECTIO

ANNULUS PUMP PIT LEAK DETECTIO

ANNULUS LK DET ELMNT TK-106-AP

TK-106-AP ANNULUS LEAK DET IND

LEAK DETECTOR INDICATOR

LEAK DETECTOR INDICATOR

LEAK DETECTOR INDICATOR

LEAK DETECTOR INDICATOR

TK-108-AP LEAK DETEC INDICATOR

COMMON LEAK DETECTOR FAILURE A

COMMON LEAK DETECTOR FAILURE A

ANNULUS PUMP PIT SUMAP LEVEL EL

ANNULUS PUMP PIT SUMP LEVEL EL

TK-106-AP AUTO LIQ LEV ELEMENT

TK-106-AP HIGH LIQ LEVEL PROBE

. TK-106-AP MAN LIQ LEVEL ELEMNT

TK 108-AP AUTO IIQ LEVEL ELMNT

TK-108-AP HIGH LIQ LEVEL PROBE

TK-108-AP MAN LIQ LEVEL ELEMNT

TK-106-AP LEVEL INDICATOR

TK-108-AP MANUAL LEVEL INDCTR

TK-106-AP LEVEL IND TRANSMITR .

TK-108-AP AUTO LEVEL IND XMTR

TK-106-AP HIGH LL ALARM FAILUR

TK-108-AP HIGH LL ALARM FAILUR

LEVEL FAILURE ALARM-ANNULUS PU

P-106-1 MANUAL SWITCH

P-108-1 MANUAL SWITCH

241-AP PWR DIST CTR "C" INSP \&

241-AP PWR DIST CTR "D" INSP \&

241-AP DIST PNLS LOAD CK-THERM

TK-106-AP PRESSURE ALARM-VAC

TK-106-AP PRESSURE ALARM-EXCES

TK-108-AP PRESSURE ALARM-VAC

TK-108-AP PRESSURE ALARM-EXCES

PRES ALRM VAC LOSS TKS-101-108

PRES ALRM-EXC VAC TKS-101-108

TK 106-AP PRES. ALM SW. LOSS 0

TK 106-AP PRES. ALM SW. EXCESS 


\section{CALIBRATION DATASHEETS REQUIRING MODIFICATIONS}

Somponent Number

PAS-108-1

PAS-108-2

PI-22-5

PI-24-6

PI-IA-106

PI-IA-108

PI-VP-108-AP

PI-WP-106-AP

PR-106-1(AP006-4)

PR-106-2(AP006-5)

PR-108-1

PR-108-2

PRV-IA-106

PRV- IA-108

PT-106-1(AP006-2)

PT-106-2(AP.006-3)

PT-108-1

PT-108-2

RA-106-AP-1

RA-106-AP-2

RA-106-AP-3

RA-106-AP-4

RA-108-AP-1

RA-108-AP-2

RA-108-AP-3

RA-108-AP-4

RR-106-AP-1

RR-108-AP-1

RXA-106-AP-1

RXA-106-AP-2

RXA-108-AP-1

RXA-108-AP-2

SDA-106-1(AP047-5)

SDA-106-1-AP

SDA-108-1

SDA-108-2

SRV-IA-106

SRV-IA-108

TA-106/-108-1

TA-3-C

TA-4-D

TA-K2-3

TA-K2-4

TC-3-C

TC-4-D

TDS-AP-2

TI-13

TI-14

TI-15

$T+16$

TS-106/-108HI
Activity Title

TK 108-AP PRES. ALM SW. LOSS

TK 108-AP PRES, ALM SW. EXCESS

TK-106-AP ANNULUS INLET PRESSU

TK 108-AP ANNULUS NLET PRESSU

MUX ENCL. AIR PRESSURE GAUGE

MUX ENCL AIR PRESSURE GAUGE

ANNULUS VENT CAM VACUUM GAUGE

ANNULUS VENT CAM VACUUM GAUGE

TK 106-AP PRES. RECORDER-NARRO

TK 106-AP PRES. RECORDER-WIDE

TK 108-AP PRES. RECORDER-NARRO

TK 108-AP PRES. RECORDER-WIDE

MUX ENCLOS. AIR PRESSURE REGULA

MUXX ENCLOS. AIR PRESSURE REGULA

TK 106-AP PRESSURE XMTR-NARROW

TK 106-AP PRESSURE XMTR-WIDE R

TK 108-AP PRESSURE XMTR-NARROW

TK 108-AP PRESSURE XMTR-WIDE R

TK-106-AP ANNULUS RADIATION AL

TK-106-AP ANNULUS RADIATION AL

TK-106-AP ANNULUS RADIATION AL

TK-106-AP ANNULUS RADIATION AL

TK-108-AP ANNULUS RADIATION AL

TK-108-AP ANNULUS RADIATION AI

TK-108-AP ANNULUS RADIATION AL

TK-108-AP ANNULUS RADIAITON AL

TANK 106-AP ANNULUS RADIATION

TANK 108-AP ANNULUS RADIATION

TK-106-AP ANNULUS RADIATION AL

TK-106-AP ANNULUS RADIATION AL

TK-108-AP ANNULUS RADIATION AL

TF-108-AP ANNULUS RADIATION AI

P-106-1 SHUT DOWN ALARM

P-106-1 SHUT DOWN ALARM

P-108-1 SHUT DOWN ALARM

P-108-1 SHUT DOWN ALARM

MUX ENCH. SAFETY RELIEF VALVE

MUX ENCL. SAFETY RELIEF VAIVE

TK-106/108 STACK CAB TEMP ALAR

INTAKE STATION C HEATER FAILUR

INTAKE STATION D HEATER FAILUR

INTAKE STATION C HEATER FAILUR INTAKE STATION D HEATER FAILUR HTR K2-2-3 TEMP CONTR STA C INTAKE STATION HEATER TEMP CO 241-AP FARM TEMPERATURE DISPLA STATION C TEMPERATURE INDICATO STATION C TEMPERATURE INDICATO STATIOND TEMPERATURE NDICATO STATION D TEMPERATURE INDICATO TK-106/108-AP STACK CAB FAN SW 
HNF-2199, Rev. 0

\section{CALIBRATION DATASHEETS REQUIRING MODIFICATIONS}

Component Number

TS-106/-108LOW

WT-YYC-300 CKTS 1-16

WT-YYC-300-CKTS-17-32

WT-YYC-300-CKTS-33-48

WT-YYC-300-CKTS-49-64

AP106-PRES3URE

AP108-PRESSURE

241-AP-XFER-SYS

24.1-AP-ANN-LDK

AP241-EDS-MCC-002
Activity Title

TK-106/108-AP STACK CAB HEATER AP FARM SN/SL LINE HEAT TRACE AP FARM SN/SL LINE HEAT TRACE AP FARM SN/SL LINE HEAT TRAE AP FARM SN/SL LINE HEAT TRACE AP106 PRESSURE FUNCTIONAL TEST AP108 PRESSURE FUNCTIONAL, TEST FUNCTEST TRANSFER LEAK DET PERFORM AN LEAK DET FUNC TEST AP241 ELECT MCC INSP \& MAINT 
HNNF-2199, Rev. 0

APPENDIX

COMPONENT DATASHEETS REQUIRING MODIFICATIONS 
HNF-2199, Rev. 0

\section{COMPONENT DATASHEETS REQUIRING MODIFICATIONS}

Component Number

241-AP-ANN-IDK

241-AP-XFER-SYS

A-40-106-TK-PSYCH

A-40-108-TK-PSYCH

A-41-106-ANN-PSYCH

A-41-108-AND-PSYCH

AI-106-1-AP

AI-106-2-AP

AI-108-1

AI-108-2-AP

AP106-PRESSURE

AP106-PRESSURE

AP108-PRESSURE

AP241-VTA-FLT-222

AP241-VTA-FLT-232

AP904-WSTA-CAM-106

AP904-WSTA-CAM-108

CVT-106-AP-1

CVT-108-AP-1

DPA-K2-10

DPA-K $2-13$

DPA-K2-14

DPA-K2-9

DPI-106-1-AP

DPI-106-2-AP

DPI-108-1

DPI-108-2

DPIS-10-6

DPIS-13-5

DPIS-14.6

DPIS-9-5

EDS-DP-311

EDS-DP-312

FA-106-AP-1

FA-108-AP-1

FAS-106-AP-1

FAS-108-AP-1

FI-106-2(AP)

FI-106-3-AP

FI-106-4-AP

FI-106-5(AP)

FI-106-6(AP)

FI-108-1

FI-108-2

F[-108-3

EI-108-4

FI-108-5

FI-108-6

HTA-AP-I

HTA-AP-2

HTTC-STA-C-1
Name

DOUBLE SHELL TANK

AP FARM TRANSFER SYSTEM LDKS

106 TK PSYCH

108 TK PSYCH

106 ANN PSYCH

107 ANN PSYCH

SUPERNATANT PUMP AMMETER - 1.0

SUPERNATANT PUMP AMMETER - 1.0

SUPERNATANT PUMP AMMETER - 1.0

SUPERNATANT PUMP AMMETER - 1.0

IOSR PRESSURE FUNCTIONAL TEST

IOSR PRESSURE FUNCTIONAL TEST

IOSR PRESSURE FUNCTIONAL TEST

105/106 ANN INLT FLT K2-4-3

107/108 ANN INLT FLT K2-4-4

(106AP) CAM

(108AP) CAM

RAN 106-1 INPUT CONVERTER MV/V

RAN 108-1 INPUT CONVERTER MV/V

INTAKE STATION D HEPA DP ALARM

INTAKE STATION C PREFILTER DP

INTAKE STATION D PREFILTER DP

INTAKE STATION C HEPA AP ALARM

TK-106-AP PRESSURE INDICATOR

TK-106-AP ANNULUS PRESSURE-STA TK 108-AP PRESSURE INDICATOR TK 108-AP ANNULUS PRESSURE-STA INTAKE STATION D HEPA DP INDIC INTAKE STATYON C PREFILTER DP INTAKE STATION D PREFILTER DP INTAKE STATION C HEPA DP NDIC 241AP MINI PWR CENTER (STA C) 241AP MINI PWR CENTER (STA D) TK-106-AP ANNULUS CAM LOW FLOW TK-108-AP ANNULUS CAM LOW FLOW TANK 106-AP ANNULUS CAM LOW FL TANK 108-AP ANNULUS CAM LOW FL FLOW INDICATOR -2.0

FLOW TRANSMITTER

FLOW INDICATOR

FLOW INDICATOR

FLOW INDICATOR

PURGE AIR ROTOMETER

FLOW INDICATOR -2.0

FLOW INDICATOR

FLOW INDICATOR

FLOW INDICATOR

FLOW INDICATOR

241-AP COMMON HEAT TRACE TROUB

241AP COMMON HEAT TRACE TROUBI INTAKE STATION C HEAT TRACE TH 
HNF-2199, Rev, 0

COMPONENT DATASHEETS REQUIRING MODIFICATIONS

HTTC-STA-D-1

LA-106-1 (AP115-2)

LA-108-1

LAM-106-1

LAM-108-1

LDA-106-1(AP140-4)

LDA-108--1

LDA-A-1

LDA-A-2

LDA-B-1

LDA-B-2

LDE-06A(AP173-1)

LDE-06B-1-AP

LDE-08A

LDE-08B-1

LDE-106-2

LDE-106-3(AP141-1)

LDE-106-4(AP142-1)

IDE-108-2

LDE-108-3

LDE-108-4

LDI-106-2(AP140-2)

LDI-106-3(AP141-2)

LDI-106-4(AP142-2)

LDI-108-2

IDI-108-3

LDI-108-4

LDXA-A-1

LDXA-B-1

LE-06B-1

LE-08B-1

LE-106-1

LE-106-2(AP115-1)

IE-106-3(AP123-1)

LE-108-1

IE-108-2

LE-108-3

II-106-1

LI-108-1

IIT-106-1(AP107-2,)

LIT-108-I

LXA-106-1

LXA-108-1

IXA-B-1

MS-106-1-AP

MS-108-1

PA-106-1(AP006-9)

PA-106-2(AP006-8)

PA-108-1

PA-108-2

PA-A-1

PA-A-2
INTAKE STATION D HEAT TRACE TH

TK-106-AP HIGH LL ALARM

TK-108-AP HIGH LL ALARM

P-106-1 CURRENT LIMIT ALARM MO

P-108-1 CURRENT LIMIT ALARM MO

TK-106-AP ANNULUS IEAK DETECTO

TK-108-AP ANNULUS LEAK DETECTO

COMMON LEAK DETECTION ALARM-CE

COMMON LEAK DETECTION ALARM-CE

COMMON LEAK DETECTION ALARM-AN

COMMON LEAK DETECTION ALARM-AN

CENTRAL PUMP PIT LEAK DETECTIO

ANNULUS PUMP PIT LEAK DETECTIO

CENTRAI PUMP PIT LEAK DETECTIO

ANNULUS PUMP PIT LEAK DETECTIO

241-AP-106 ANN LEAK DETECTION

241-AP-106 ANN LEAK DET (TAPE)

241 AP-106 ANN LEAK DET (TAPE)

ANNULUS LEAK DETECTION TAPE

ANNULUS LEAK DETECTION TAPE

ANNULUS LEAK DETECTION TAPE

LEAK DETECTOR INDICATOR

LEAK DETECTOR INDICATOR

LEAK DETECTOR INDICATOR

LEAK DETECTOR INDICATOR

LEAK DETECTOR INDICATOR

LEAK DETECTOR INDICATOR

COMMON LEAK DETECTOR FAILURE A

COMMON IEAK DETECTOR FAILURE A

ANNULUS PUMP PIT SUMP LEVEL EL

ANNULUS PUMP PIT SUMP LEVEL EL

TK 106-AP AUTOMATIC ITQUID LEV

TK-106-AP HIGH IL PROBE

TK 106-AP MANUAL LIQUID LEVEL

TK 108-AP AUTOMATIC LIQUID LEV

TK 108-AP HIGH LL PROBE

TK-108-AP MANUAI LXQUID LEVEL

IEVEL INDICATOR -2.0

'LEAK DETECTOR INDICATOR -2.0

IEVEL INDICATOR TRANSMITTER

LEVEL INDICATOR TRANSMITTER

TK-106-AP HIGH IL AI ARM FAILUR

TK-108-AP HIGH LL ALARM FAILUR LEVEL FAILURE ALARM-ANNULUS PU

P-106-1 MANUAL SWITCH

P-108-1 MANUAL SWITCH

TK-106-AP PRESSURE ALARM-VAC $C$

TK-106-AP PRESSURE ALARM-EXCESS

TK-108-AP PRESSURE ALARM - VAC

TK-108-AP PRESSURE ALARM-EXCESS

PRESSURE ALARM-VACUUM LOSS +.5

PRESSURE ALARM-EXCESS VACUUM + 
FNF-2199, Rev. 0

\section{COMPONENT DATASHEETS REQUIRING MODIFICATIONS}

Compenent Number

PAS-106-1-AP

PAS-106-2-AP

PAS-108-1

PAS-108-2

PII-22-5

PI-24-6

PI-IA-106

PI-IA-108

PI-VP-108-AP

PI-WP-106-AP

PR-106-1(AP006-4)

PR-106-2(AP006-5)

PR-108-1

PR-108-2

PRV-IA-106

PRV-IA-108

PT-106-1(AP006-2)

PT-106-2(AP006-3)

PT-108-1

PT-108-2

RA-106-AP-I

RA-106-AP-2

RA-106-AP-3

RA-106-AP-4

RA-108-AP-1

RA-108-AP-2,

A-108-AP-3

RA-108-AP-4

RR-106-AP-1

RR-108-AP-1

RXA-106-AP-1

RXA-106-AP-2

RXA-108-AP-1

RXA-108-AP-2

SDA-106-1(AP047-5)

SDA-106-1-AP

SDA-108-1

SDA-108-2

SRV-IA-106

SRV-IA-108

TA-106/-108-1

TA-3-C

TA-4-D

TA-K22-3.

TA-K2-4

TC-3-C

TC-4-D

TDS-AP-2

TI-13
Name

TK 106-AP PRES, ALM SW.-LOSS 0

TK 106-AP PRES. ALM SW.EXCESS

TK 108-AP PRES. ALM SW.-LOSS 0

TK 108-AP PRES. ALM SW.-EXCESS

TK-106-AP ANNULUS INLET PRESSU

TK 108-AP ANNULUS INLET PRESSU

MUX ENCL. AIR PRESSURE GAUGE

MUX ENCL. AIR PRESSURE GAUGE

ANNULUS VENT CAM VACUUM GAUGE

ANNULUS VENT CAM VACUUM GAUGE

TK 106-AP PRES. RECORDER-NARRO

TK 106-AP PRES. RECORDER-WII)E

TK 108-AP PRES. RECORDER-NARRO

TK 108-AP PRES. RECORDER-WIDE

MUX ENCLOS. AIR PRESSURE REGULA

MUX ENCLOS. AIR PRESSURE REGULA

TK 106-AP. PRESSURE XMTR-NARROW

TK 106-AP PRESSURE XMTR-WIDE R

TK 108-AP PRESSURE XMTR-NARROW

TK 108-AP PRESSURE XMTR-WIDE R

TK-106-AP ANNULUS RADIATION AL

TK-106-AP ANNULUUS RADIATION AL

TK-106-AP ANNULUS RADIATION AL

TK-106-AP ANNULUUS RADIATION AL

TK-108-AP ANNULUS RADIATION AL

TK-108-AP ANNULUS RADIATION AL

TK-108-AP ANNULUS RADIATION AL

TK-108-AP-ANNULUS RADIATION AL

TANK 106-AP ANNUULUS RADIATION

TANK 108-AP ANNULUS RADIATTON

TK-106-AP ANNULUS RADIATION AI

TK-106-AP ANNULUS RADIATION AL

TX-108-AP ANNULUS RADIATION AL

TK-108-AP ANNULUS RADIATION AL

P-106-1 SHUT DOWN ALARM -.5

P-106-1 SHUT DOWN ALARM -.5

P-108-1 SHUT DOWN ALARM -.5

P-108-1 SHUT DOWN ALARM -.5

MUX ENCL. SAFETY RELIEF VALVE

MUX ENCL. SAFETY RELIEF VALVE

TK-106/108 STACK CAB TEMP ALAR

INTAKE STATION CHEATER FAILUR

INTAKE STATION D HEATER FAILUR

INTAKE STATION C HEATER FAILUR

INTAKE STATION D HEATER FAILUR INTAKE STATION HEATER TEMP. +1 INTAKE STATION HEATER TEMP. CO 241-AP FARM TEMPERATURE DISPLA STATION C TEMPERATURE INDICATO 
HNF-2199, Rev. 0

\section{COMPONENT DATASHEETS REQUIRING MODIFICATIONS}

Component Number

TI-14

TI-15

TI-16

TS-106/-108HI

TS-106/-108LOW

WT-YYC-300 CRTS $1-16$

WT-YYC-300-CKTS-17-32

WT-YYC-300 - CKTS - 33-48

WT:YYC-300-CKTS-49-64
Name

STATION C TEMPERATURE INDICATO

STATION D TEMPERATURE INDICATOR

STATION D TEMPERATURE INDICATO

TK-106/108-AP STACK CAB FAN SW

TK-106/108-AP STACK CAB HEATER

AP FARM SN/SL LINE HEAT TRACE

AP FARM SN/SL LINE HEAT TRACE

AP FARM SN/SL LINE HEAT TRACE

AP FARM SN/SL LINE HEAT TRACE 
HNF-2199, Rev. 0

APPENDIX G

ESSENTLAL FACILITY ELECTRICAL AND

PIPING AND INSTRUMENTATION DRAWINGS (P\&IDS) 
HNF-2199, Rev. 0

\section{ESSENTIAL FACILITY ELECTRICAL AND PIPING AND INSTRUMENTATION DRAWINGS (P\&IDS)}

Drawing_Number/Sheet

H-02-0090476/1-13

$\mathrm{H}-14-0010503 / 6,8$

$\mathrm{H}-14-0020103 / 1$

$\mathrm{H}-14-0020203 / 1,2,5$

$\mathrm{H}-14-0020303 / 1,3,5$

$\mathrm{H}-14-0020503 / 6,8$

$\mathrm{H}-14-0020603 / 6,8$

$H-14-0020803 / 4$

HX-14-0021803/1

$\mathrm{H}-14-0030003 / 1,2,22,23,27,28$
Title

Electrical Elementary Diagrams

Dome Penetration Schedules

Ventilation Tank Primary System

Ventilation Tank Annulus System

Service and Instrument Air System

Waste Storage Tank Annulus Instrumentation

Waste Storage Tank Instrumentation

Waste Transfer System

Raw Water System

Electrical One Line Diagram and Panelboard Schedules 